\title{
"Volcanism in the Chugoku region: a review for the first UNESCO field school on Geoenvironmental disaster reduction"
}

\author{
Andreas Auer ${ }^{1,2}$ (D)
}

\begin{abstract}
Field studies related to natural hazards are an integral part of any disaster mitigation effort, because geological samples and field records must initially be obtained from the context in which they occur. A sound fieldwork and careful observation and documentation of field relations is crucial for meaningful subsequent laboratory work, further data analysis and modelling. Teaching the necessary practical skills that enable students to recognize natural disaster events in the geological records and to understand circumstances under which they occur is not a trivial task. Some barriers to fieldwork usually exist, especially when the teaching subject focusses on natural disasters. Beside cost and logistics it is often the lack of suitable sites, that serve as instructive examples, displaying the deposits, structures and preserved evidence of natural hazards in the geological record. To students of volcanology, southwest Japan offers an almost unparalleled variety of interesting volcanic successions, including a broad range of different volcanic landforms and deposits that illustrate the various hazards associated with volcanic eruptions. This review will provide a brief overview of the geology of southwest Japan with special emphasis on the igneous and volcanic evolution. It will give participants of the field school a minimum of required background and anybody beyond a quick introduction into one of the most diverse and interesting volcanic field areas in the world.
\end{abstract}

Keywords: Arc volcanism, Volcanic hazards, SW Japan, Daisen volcano, Sanbe volcano

\section{Introduction}

Geoenvironmental hazards are not evenly distributed across the Earth and many of them concentrate in areas of active tectonism (Berz et al. 2001). The detailed mechanism that causes a natural disaster is often not available for direct observation (Hasegawa et al. 2011). In addition, the recurrence of events deduced from the geological record of an area, may provide important information about the probability of future events. For all these reasons, much information can be obtained from the geological record. The frequency of tsunamis in a certain area may be recorded in costal sedimentary successions, which have preserved a record of previous tsunami deposits (Minoura and Nakata 1994). The occurrence and characteristics of landslides is closely linked to subsurface stratigraphy (Song et al. 2019) and outcrops of fault zones provide

\footnotetext{
Correspondence: auer@riko.shimane-u.ac.jp

${ }^{1}$ Department of Geoscience, Shimane University, Matsue 690-8504, Japan ${ }^{2}$ Project Center on Natural Disaster Reduction, Shimane University, Matsue 690-8504, Japan
}

essential information on fault zone kinematics and structure, which help to understand earthquake rupture mechanisms (Mukoyoshi et al. 2018).

The active processes occurring during large explosive volcanic eruptions are equally difficult to study, because of the inherent danger. In addition, critical stages preceding a volcanic eruption such as the initial formation of the melt and its composition, the amount of magma that can erupt and the style of the forthcoming eruption cannot be studied directly. Thus, examination of wellpreserved deposits from previous eruptions and exposed sections of the shallow and deeper crust can provide important information on magma genesis and diversification and will help to understand style and potential hazards of an forthcoming eruption. An ideal field area would thus provide a record of the deeper crust with outcrops of intrusive rocks, showing the structure of ancient magmatic systems as well as the deposits of a variety of different modern volcanic successions, emplaced 

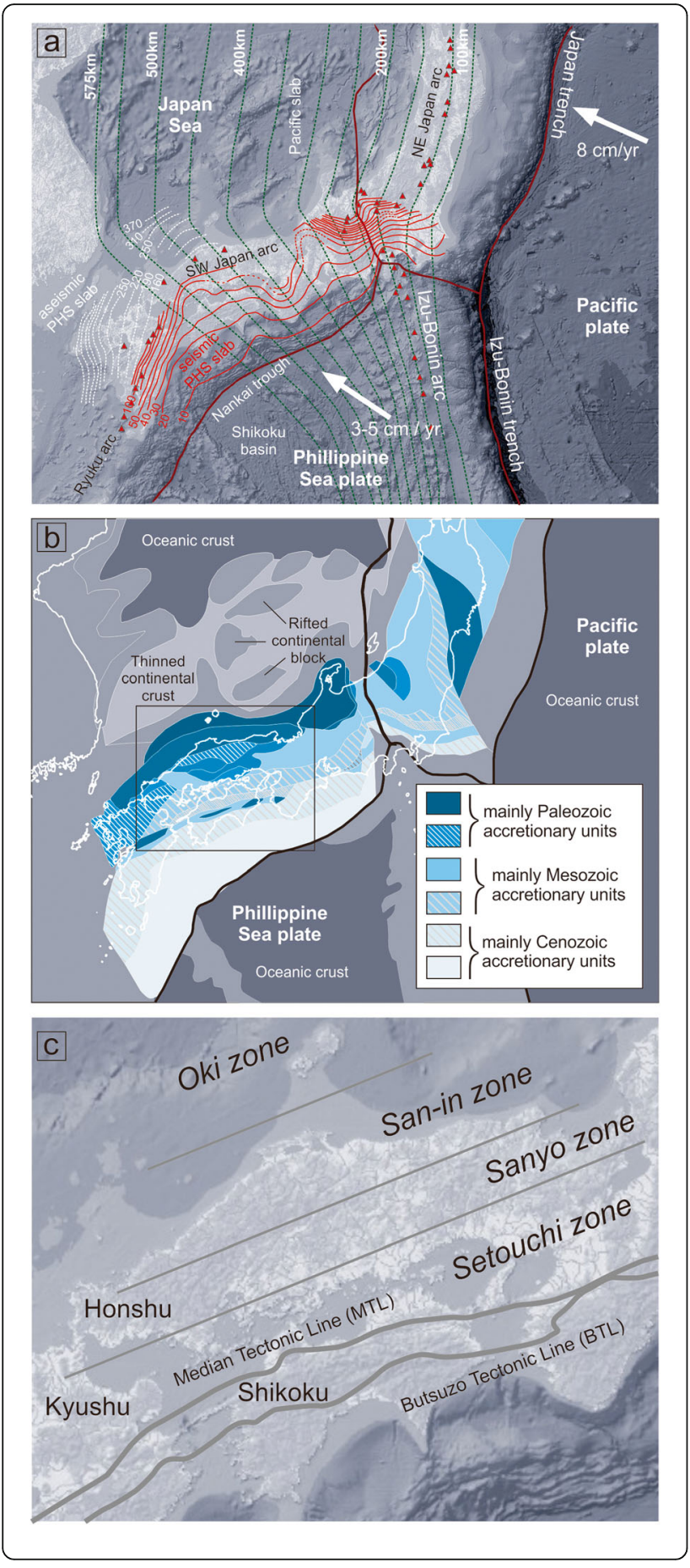

Fig.1 a Tectonic setting, showing individual arc segments and subduction zones of the Japanese island arc system (Kimura et al. 2014). Notice the distinct trench morphology between the NE Japan arc and the SW Japan arc. Seismic tomography shows the deep slab of the Pacific plate (in green) and the Philippine Sea Plate (red - seismic, white - aseismic) from Zhao et al. (2012). b: Basement geology map of the Japanese arc system (Taira 2001). Several tectonic units have been summarized for simplicity and intrusive rocks have been excluded. A progressive younging of individual units from an inner zone (adjacent to the Japan Sea) to the outer zone (Nakai trough) is particularly well developed in SW Japan. Basement units in the back-arc region include new continental crust as well as thinned and rifted older cratonic crust. c: names of distinct geographical and geological zones within SW Japan. The westernmost region of Honshū, is also known as the chūgoku region.

during volcanic activity characterized by different style, magnitude and occurring in different geological settings.

SW Japan has been a volcanic arc since the Paleozoic, and it is still an active arc today. Its evolution started as an active continental margin, comparable to the continental arc in modern South America. Subsequently, continental rifting and opening of a back-arc basin separated a segment of continental crust from the Asian mainland and initiated subduction along a new arc segment. Such a long and diverse geologic history has preserved a unique record of volcanic successions allowing to obtain a comprehensive picture of the nature of volcanic phenomena. This review provides a summary of the tectonic and magmatic evolution of SW Japan and introduces representative field occurrences, which serve as a narrative for the long evolution of this magmatic arc segment. The final section will discuss some of the most common volcanic hazards, which are in large part associated with Quaternary volcanism in SW Japan.

\section{Geological background Tectonic setting}

Japan is an arcuate narrow island arc of more than 3000 $\mathrm{km}$ length, located at the western margin of the Pacific Ocean, and on the eastern margin of the Asian landmass. Japan is located above a convergent plate boundary with several active segments, which (from north to south) are: the Kurile arc, the NE Japan arc, the Izu-Bonin arc, SW Japan arc and the Ryukyu-Kyushu arc (Fig. 1a).

The evolution of the Japanese arc system began during the Paleozoic along the eastern Asia continental margin (Wakita 2013). Subduction of the Proto Pacific Ocean floor and accretion of Mesozoic and Paleogene sediments initially constructed a Cordilleran-Type continental arc (Fig. 2a), which forms much of the basement of modern SW Japan (Taira 2001). Basement terranes are aligned subparallel to the arc and contain a comprehensive record of the evolution of the continental margin of eastern Asia. The oldest rocks (gneiss and amphibolite) 

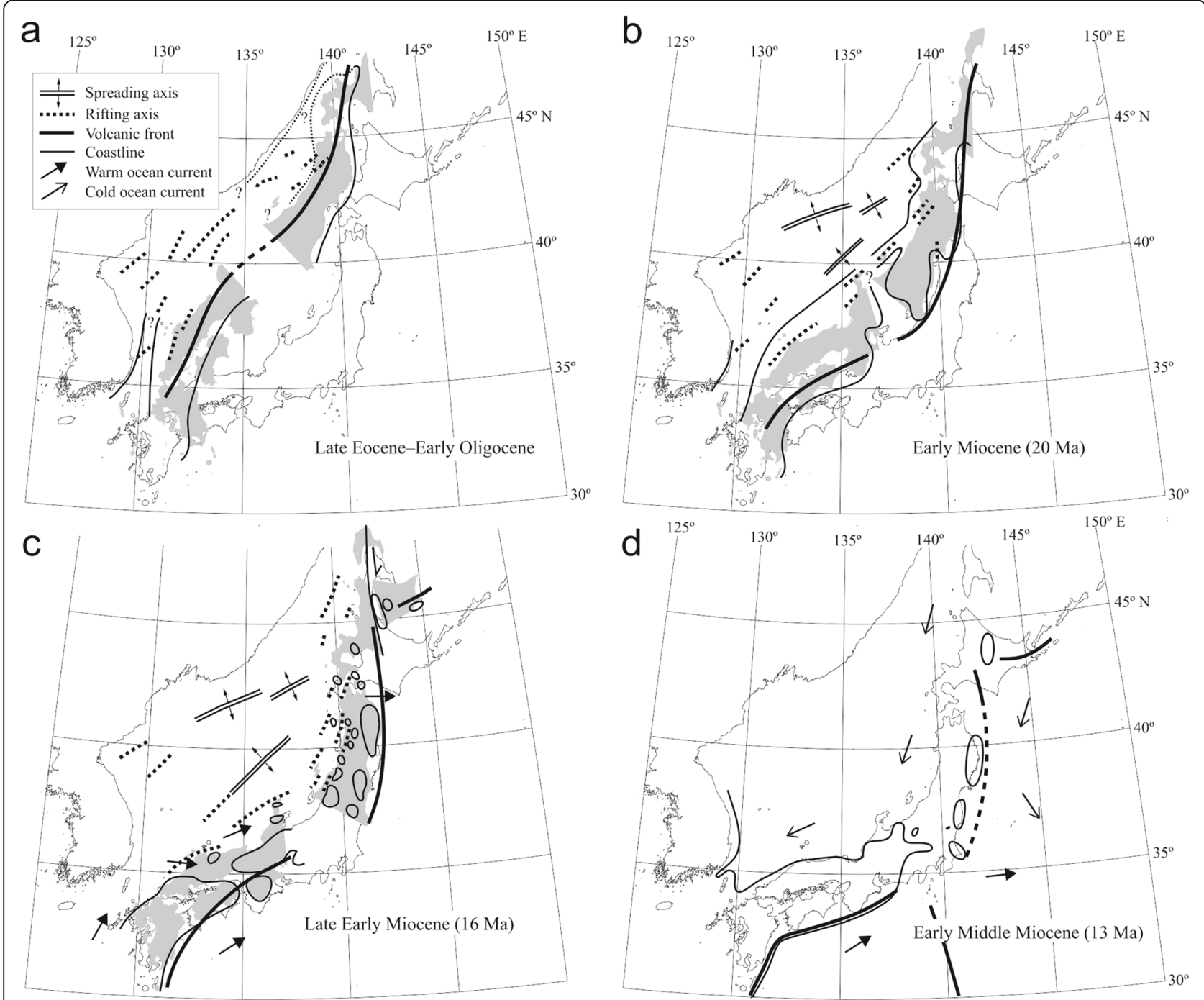

Fig. 2 Selected stages, showing the Paleogeographic evolution of Japan. Detailed description of the different stages is in the text. a: Continental arc stage, before $30 \mathrm{Ma}$. Subduction of (proto) Pacific plate has formed a large continental arc due to accretion and igneous activity at the margin of SE Asia. The first image already emphasizes the beginning evolution of a new rift system. $\mathbf{b}$ : This rifting stage is marked by a change in igneous activity and the onset of sedimentation related to basin evolution at Shimane peninsula. c: Peak rifting stage with the formation of new oceanic crust in the back-arc region and clockwise rotation of SW Japan into its current paleogeographic location (d) (from Kano 2018)

found in the San'in region of SW Japan consist of highly metamorphosed cratonic lithosphere (Fig. 1b). Additional fragments of ancient crust were "stranded" within the Japan Sea during active back-arc rifting including Paleozoic gneisses found on Oki Island (Suzuki and Adachi 1994). Subsequently accreted terrane, which show progressive younging eastwards towards the current trench location, include Paleozoic - Triassic rocks in the San'in and San'yō zone and Jurassic rocks of the Setouchi zone (Fig. 1b). The zone between the Median Tectonic Line (MTL) and the Butsuzo Tectonic Line (BTL, Fig. 1c) contains a metamorphosed Jurassic accretionary prism, the well-known paired metamorphic belts first identified by Miyashiro (1961). Several studies have discussed the detailed architecture and mechanics of these fossil subduction zones (Takasu 1989; Endo et al. 2015). The youngest units in the arc segment are found in the Cretateous - Neogene accretionary prism of the Shimanto belt (Taira 2001). During the successive accretion of material to the continental margin, ongoing subduction also produced large volumes of intrusive and contemporary volcanic rocks (Fig. 3a), generating substantial amounts of new continental crust.

During the Paleogene (Fig. 2a), extensional tectonic and significant crustal thinning initiated the separation of Japan from the Asian mainland (Jolivet et al. 1994; Maruyama et al. 1997). This was accompanied by a widespread igneous activity (Fig. 3b), which produced extensive silicic magmatism along the newly initiated rift 

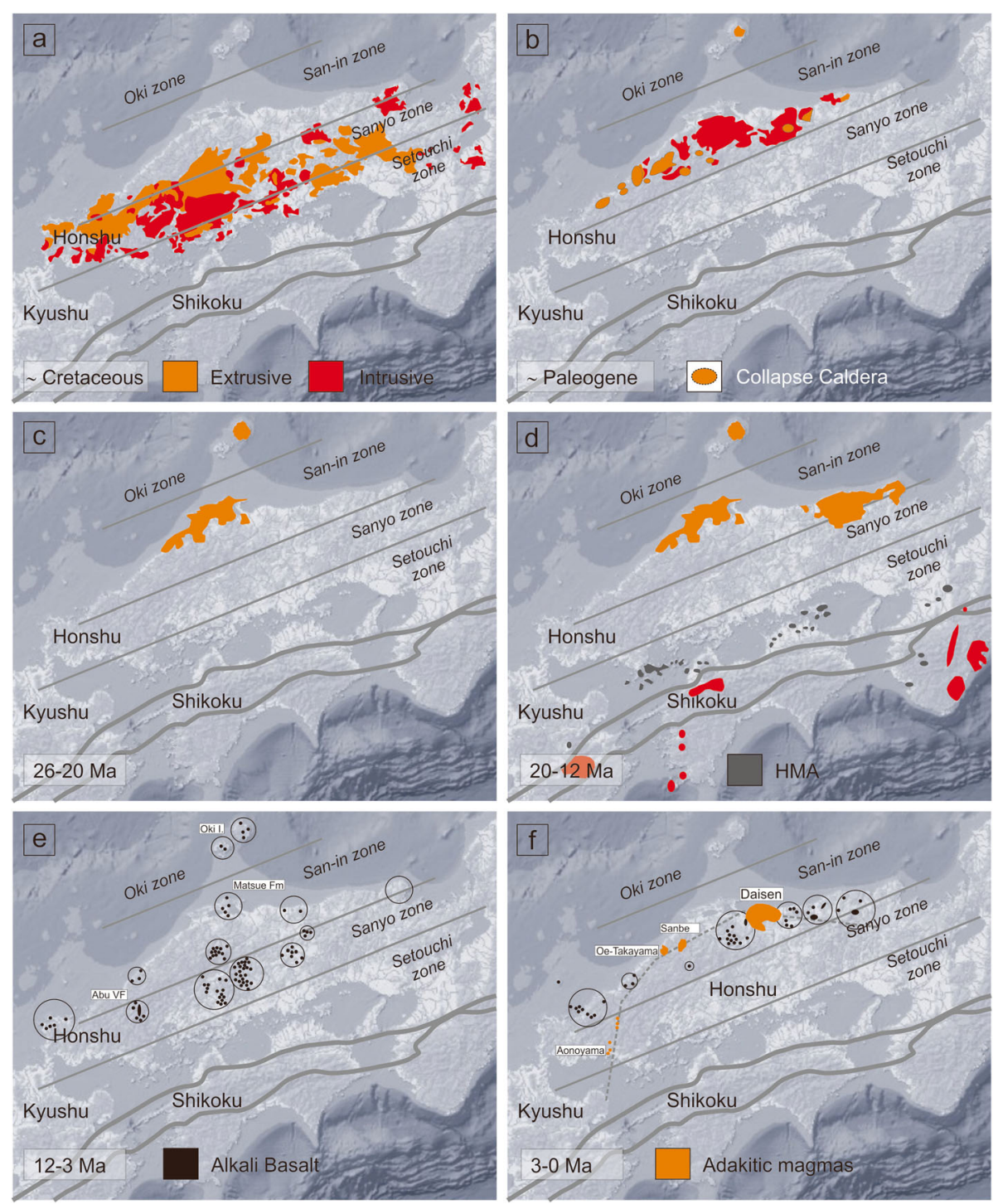

Fig. 3 Magmatic evolution of the SW Japan arc segment (detailed description of individual stages in the text) a: Continental arc stage, formed by a large number of granitic intrusions and associated extrusive rocks, of mainly Cretaceous age. b: Paleogene continental arc stage (second igneous flare up) which precedes the subsequent rift initiation. Many of the volcanic successions of this stage are preserved in relation with collapse caldera structures. c: Back-arc rift initiation starting with continental volcanism - subsequently changing to sub lacustrine / marine stages. d: Ongoing (mainly submarine volcanism in the back-arc basin with contemporary onset of diverse igneous activity in the fore-arc, marking the beginning subduction of the PSP. e: Evolution of several monogenetic volcanic fields, mainly alkali basalt volcanism. $\mathbf{f}$ : Ongoing monogenetic alkali basalt volcanism and coeval evolved adakitic magmatism (Nakajima 1996; Kimura et al. 2005a; Imaoka et al. 2011; Sato et al. 2016)

(Imaoka et al. 2011). During the late Paleogene a significant reconfiguration of the regional stress field occurred in the western Pacific, initiating the opening of the Japan Sea (Fig. 2b,c). This event has been studied in great detail from a tectonic perspective (Otofuji et al. 1985; Jolivet et al. 1994; Nakajima 2018), a stratigraphic / sedimentological perspective (Ingle 1992; Kano et al. 2007; Kano 2018) and an petrological perspective (Table 1). Since the Eocene (ca. 44 Ma), several tectonic episodes occurred with simultaneous characteristic magmatic activity and contemporaneous local basin evolution.
Sedimentary successions around the Japan Sea document the transition from continental to a fully marine setting beginning in the late Eocene and continuing through to the Miocene (Ingle 1992; Kano et al. 2007). Back-arc rifting and clockwise rotation of SW Japan (Otofuji et al. 1985) finally initiated subduction of the Philippine Sea Plate along a new arc, to accommodate the formation of new oceanic crust in the Japan Sea back-arc basin (Fig. 1a). Individual stages of the tectonic evolution are accompanied by characteristic igneous-tectonic associations, which will be discussed below. 
Table 1 Simplified stratigraphic table (with special emphasis on SW Japan) showing major tectonic events alongside with basin development and igneous activity which will be further discussed in the text.
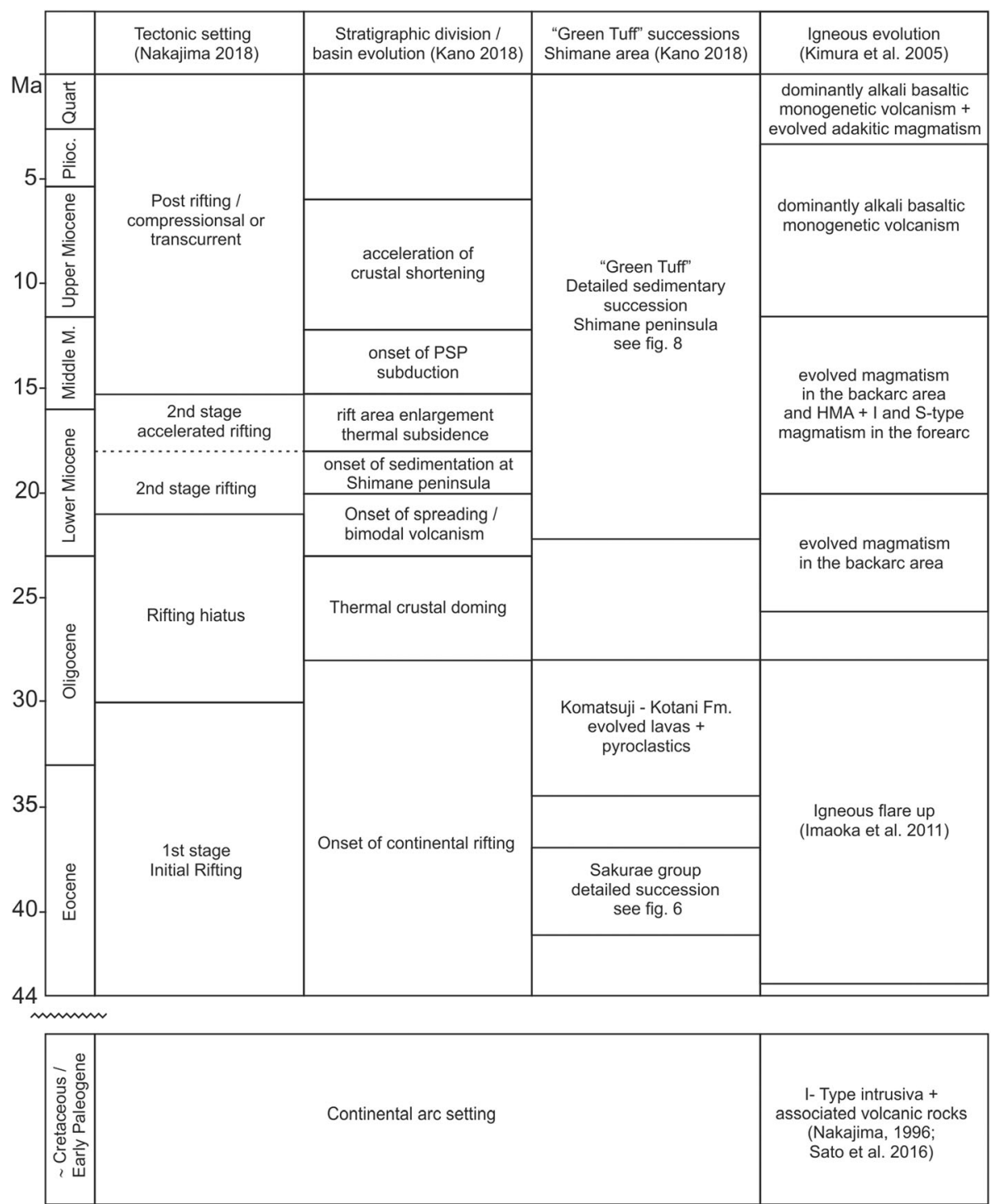

\section{Magmatic evolution of the SW Japan arc}

Several igneous-tectonic associations and magma series have been identified and are briefly defined here. Terminology and references are given in Table 2 .

\section{Early Adakites (early cretaceous)}

Earliest evidence for arc magmatism in SW Japan is preserved in isolated occurrences of early Cretaceous I-type granitic intrusions with adakitic chemistry (Kiji et al. 2000; Kamei 2004). Their formation is related to subduction of one of the (proto) pacific plates (Izanaki / Kula) along the eastern margin of the Asian continent (Domeier et al. 2017). Geochemical characteristics generally suggest subduction and melting of a young, hot slab (Table 1). These "old adakites" are some of the earliest evidence of subduction around the Pacific Ring of Fire (Kamei et al. 2004; Imaoka et al. 2014a).

\section{Continental arc stage (cretaceous - early Paleogene)}

Subduction continued at the eastern Asian continental margin during the Cretaceous and early Paleogene forming a large batholite belt (Fig. 3a, Fig. 4) comparable to Andean batholiths with associated caldera-forming silicic volcanism (Nakajima 1996; Sato et al. 2016). Igneous intrusions have been further divided into distinct magmatic episodes (Nishida et al. 2005) and have also been studied in terms of along arc variations (Nakajima et al. 1990). In addition, intrusive rocks of SW Japan have been subject of some influential petrological studies about growth of continental crust and granite petrogenesis (Ishihara 1977; 
Table 2 Igneous-tectonic associations, modified after Wilson (2007)

\begin{tabular}{|c|c|c|c|c|}
\hline & \multicolumn{2}{|l|}{ Plate Margin } & \multicolumn{2}{|l|}{ Intra Plate } \\
\hline & Convergent & Divergent & Intra Oceanic & Intra-Continental \\
\hline $\begin{array}{l}\text { Igneous-tectonic } \\
\text { associations }\end{array}$ & $\begin{array}{l}\text { - Island Arcs } \\
\text { - Continental Arcs } \\
\text { - Young (<25 Ma) } \\
\text { subduction zones }\end{array}$ & $\begin{array}{l}\text { - Mid ocean ridge } \\
\text { basalt (MORB) } \\
\text { - Back-arc spreading centres }\end{array}$ & - Oceanic Islands (OIB) & $\begin{array}{l}\text { - Continental rift zones } \\
\text { - Continental Intraplate } \\
\text { Volcanism }\end{array}$ \\
\hline Magma Series & $\begin{array}{l}\text { - Tholeiitic } \\
\text { - Calk-Alkaline } \\
\text { - Alkaline } \\
\text { - Adakite, HMA }\end{array}$ & - Tholeiitic & $\begin{array}{l}\text { - Tholeiitic } \\
\text { - Alkaline }\end{array}$ & $\begin{array}{l}\text { - Tholeiitic } \\
\text { - Alkaline }\end{array}$ \\
\hline $\mathrm{SiO}_{2}$ range & $\begin{array}{l}\text { - basalts and } \\
\text { differentiates }\end{array}$ & - basalts & $\begin{array}{l}\text { - basalts and } \\
\text { differentiates }\end{array}$ & - basalts and differentiates \\
\hline
\end{tabular}

-Alkaline vs Subalkaline rocks. Distinguished within the Total Alkali vs Silica diagram (TAS) but on different discrimination functions (Irvine and Baragar 1971; Miyashiro 1978; LeBas et al. 1986).

-Subalkaline rocks are further distinguished into a Tholeiitic and a Calc-alkaline series by different criteria (Irvine and Baragar 1971; Miyashiro 1974). -Adakites and High Magnesium Andesites (HMA). Magmas from young, hot subduction zones (e.g. SW-Japan arc) show distinct characteristics in comparison with those from old mature subduction zones (e.g. NE-Japan arc). The difference is related to the thermal structure of the subduction zone and the possibility to directly melt the subducted oceanic lithosphere (Kay 1978; Defant and Drummond 1990). Adakites and associated rock types also occur in other settings where their origin is debated. For a review see Martin et al. (2005).

-I-Type vs. S-Type intrusiva distinguished on the basis of igneous (I) and sedimentary (S) source rocks (Chappell and White 1992)

Nakajima et al. 2004). Their exposure at different crustal levels provides an excellent opportunity to study igneous processes and magma dynamics in ancient magma chambers and link these results to the active recent magmatic systems (Czamanske et al. 1981; Kawakatsu and Yamaguchi 1987; Yakushiji et al. 2012).

\section{Second igneous "flare up" (43 - $30 \mathrm{ma}$ )}

Igneous activity ceased for a short period between 52 and $43 \mathrm{Ma}$ (Nishida et al. 2005) but subsequently resumed, starting with a second igneous "flare up" (Fig. 3b, Fig. 4) between 43 and $30 \mathrm{Ma}$ (Imaoka et al. 2011). This period of igneous activity still contains continental arc characteristics and produced granitic intrusions and voluminous silicic volcanism (Matsuda and Oda 1982). Geochemical characteristics within the second episode are not uniform, but show a number of subtle characteristics which may reflect a change in tectonic setting such as a slowing of the convergence rate of the Pacific Plate (Northrup et al. 1995), and initiation of an arc-parallel rift system (Imaoka et al. 2011). This beginning intra-arc rifting is accompanied by some of the earliest rift related sediments around the Japan sea (Kano et al. 2007; Kano 2018).

\section{Initiation of back-arc rifting / back-arc spreading (28 - 17 ma)}

This episode marks the final transition from a convergent plate boundary to a divergent one. Igneous-tectonic associations and their respective magma series show hybrid characteristics and don't provide a simple unambiguous signal. Volcanic rocks are generally mafic to felsic tholeiitic which may show a relict subduction signature inherited from the lithosphere of the CretateousPaleogene continental arc (Uto et al. 1994). Rift related volcanism in the San'in region during this period is associated with deposition of terrigenous sedimentary successions that provide a seamless transition from terrestrial to open marine facies (Sakai et al. 2013).

\section{Peak rifting stage $(18 \sim 15.3)$ and onset of PSP subduction (15.3 $12 \mathrm{ma}$ )}

Around 16.5 Ma, magmatism began parallel to a broad zone in the fore-arc of SW Japan (Fig. 3d., Fig. 4). This activity marks the onset of the Philippine Sea Plate (PSP) subduction in direct consequence of extensive back-arc rifting. I-type and S-type felsic magmas (Table 2) and High magnesium andesites (HMA) were derived by melt formation at the leading edge of the PSP. Chemical compositions are diverse due to the complex interaction of slab derived melts with overlying crust and sediment (Kimura et al. 2003, 2005a, 2014). At the same time, dominantly tholeiitic igneous activity continued in the back-arc region. This activity is associated with rift related asthenospheric mantle flow related to the evolution of the back-arc rift. Though the principle magma type is tholeiitic, variable degree of melting and interaction with thinned continental crusts (Fig. 1b) can account for the hybrid nature of these rocks (Morris and Kagami 1989; Morris et al. 1990; Miyake 1994).

\section{Monogenetic alkali basalt fields (12-4 ma)}

Fore-arc activity ceased around $12 \mathrm{Ma}$ with the leading edge of the PSP now slowly propagating towards NE below SW Japan. No subduction related calc-alkaline active volcanic front has yet developed. Instead, this stage is marked by a diffuse activity of monogenetic volcanism, sweeping over the SW-Japan arc (Fig. 3e). Chemical compositions vary between tholeiitic and oceanic island basalts, but alkali basaltic compositions predominate, some which are highly silica undersaturated (Tatsumi 


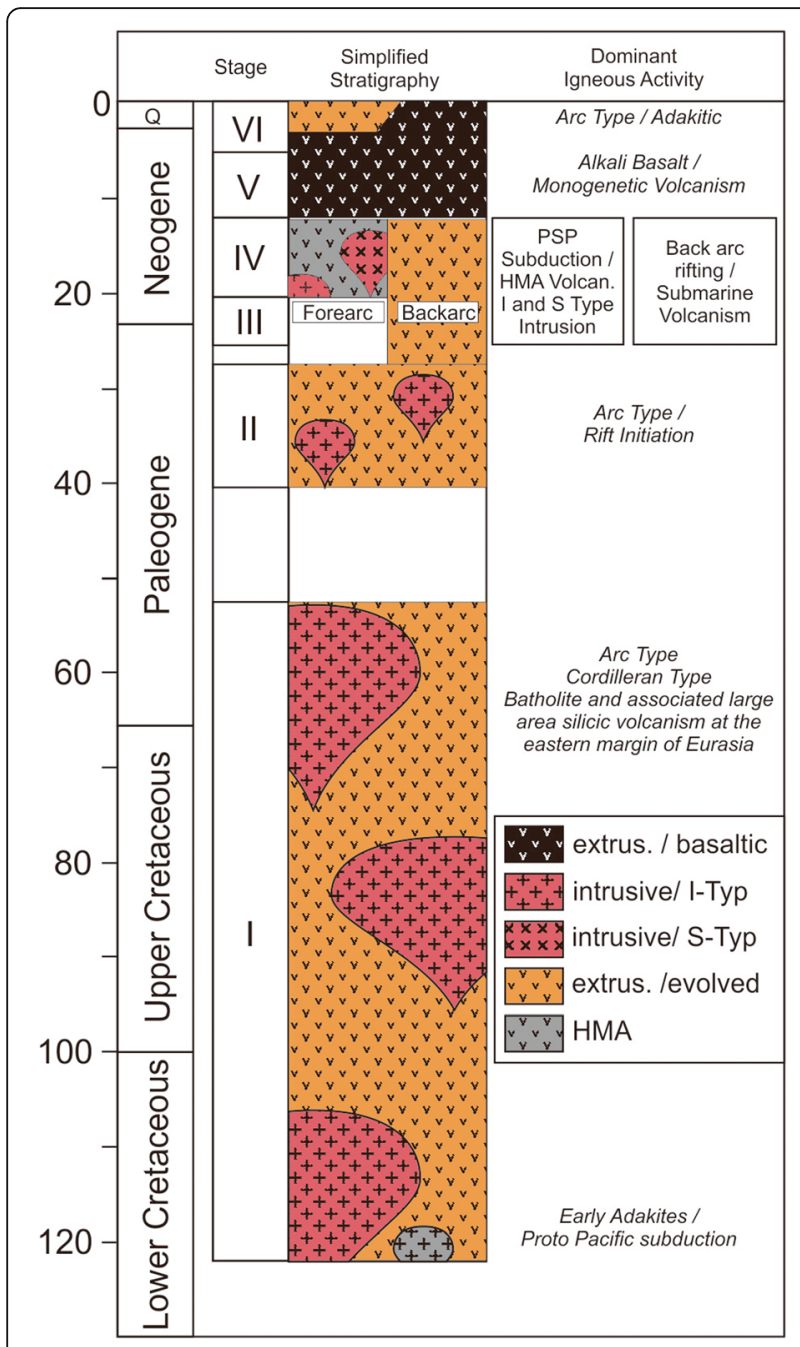

Fig. 4 Simplified stratigraphic evolution of the SW Japan arc. Individual stages are described in the text. HMA - High Magnesian Andesite, AD - Adakite are hallmarks of subduction initiation of a new young plate. Stage IV shows distinct evolution between for-arc and back-arc. See text for detailed description of individual stages and further reading

et al. 1999). The majority of volcanic rocks on the backarc side (Matsue Formation) also show hybrid characteristics between alkaline and subalkaline compositions with highly variable trace element compositions (Morris and Itaya 1997). No simple geochemical classification is sufficient to confidently identify a single magma source and two general scenarios have been discussed (which may work alone or in concert): One source could be an effect related to subduction of the leading edge of the Philippine Sea Plate (Valentine and Connor 2015), the possible effect of the downward propagating slab is further discussed in the next paragraph. The second potential effect could be related to asthenospheric mantle flow (related to back-arc rifting) into the mantle wedge between SW Japan and the deep Pacific Slab (Fig. 1a). This mantle may form melt anomalies that interact to varying degrees with older thinned continental lithosphere.

\section{A new volcanic front in SW Japan (3 ma to present)}

After another hiatus between 4 and $3 \mathrm{Ma}$ volcanic activity resumed in the San'in and Oki zone (Fig. 3f). This phase is dominated by the evolution of several large complex stratovolcanoes. Morris (1995) pointed out the adakitic composition of these eruptive centers. This stage therefore marks the advent of the Philippine Sea Plate at sufficient depth for arc magma generation, but also shows that these magmas are directly derived by slab melting of the PSP. Most of the adakitic eruptive centers are associated with previous or ongoing activity in the alkali basaltic monogenetic volcanic fields. Cogenetic evolution of these basalts together with the adakitic magmas was interpreted as magmas formed at "slab tears", providing the required chemistry and heat source for this type of bimodal volcanism (Pineda-Velasco et al. 2018).

\section{Volcanic field relations in the SW Japan arc}

The following section is revisiting the previous stages of the evolution of SW Japan from a volcanological perspective. To comprehensively understand a "volcano-magma system" (Schmincke 2004) one has to consider processes, starting with the formation of melt (usually in the mantle), its accumulation and diversification during ascent through the crust, the eruptive environment and style of eruption as well as transport and deposition of the erupted materials. Most of these processes are inaccessible for direct observation, because they either occur underground, or are too dangerous to study close up. By backtracking the evolution of the SW Japan arc, it is also possible to study the volcano-magma system from the roots to the modern landforms and their associated deposits.

Erosion has exposed sections through a variety of continental and submarine volcanic systems at different depths. Key research topics in volcanology are briefly discussed and examples from the current literature are reviewed with special emphasis on this field area.

\section{Intrusive rocks of the continental arc stage - ancient magma chambers and the roots of arc volcanoes}

The physical relation between intrusive rocks and genetically related volcanic rocks is difficult to reconcile because apart from a few rare examples (Marsh 2004), only one or the other is commonly exposed. While it is possible to sample and analyze true liquid magma compositions during volcanic eruptions, information about the magmatic plumbing system is only available via geophysical methods. Such information is generally of low resolution, and although at the frontier of current research (Kahl et al. 2013; Tomiya et al. 2013), it remains difficult to link geophysical information to distinct magmatic 
processes. On the other hand, many igneous intrusions are the remnants of active arc magma chambers. However, their solidification often obliterates the dynamic connection between a magma chamber and an active volcanic system. Key questions are the diversification of magmas from their basaltic parental magmas, storage conditions and the architecture of arc magma chambers (Cashman et al. 2017). Intrusive rocks that have preserved evidence of the dynamic processes in arc magma chambers are well preserved in SW Japan (Yamaguchi et al. 2003; Wada et al. 2004) and some notable examples are briefly mentioned here: An example of a compositionally zoned magma chamber is described by Imaoka et al. (2014b) from the Hobenzan pluton in SW Japan. The authors show how differentiated volatile rich melts segregated from a crystal mush and accumulate in the roof region of a subvolcanic magma chamber. The upward percolation of buoyant low density interstitial melt, supported by the exsolution of a gas phase is known as filter-pressing (Bachmann and Bergantz 2004). Complementary to their model is the observation that many modern volcanic successions show systematic compositional variation during the course of an eruption (usually starting with the most gas rich, evolved magma to successively less evolved compositions). This suggests that many volcanic eruptions are tapping into compositionally zoned magma storage systems (Watanabe et al.
2006; Nakagawa et al. 2011; Auer et al. 2015, 2016). Yakushiji et al. (2012) described mingling textures in an early Paleogene quartz-diorite - tonalite - leucogranite intrusion from the San'in zone. Magma mixing and mingling are important processes leading to magma diversification (Eichelberger 1975) and occur in intrusive as well as extrusive rocks (Browne et al. 2006). Several additional examples of magma mixing / mingling have been described from SW -Japan highlighting the importance of these processes in the subvolcanic system (Fig. 5). Ishihara and Tani (2004) discuss combined effects of magma fractionation and mixing and Shin et al. (2009) discuss magma mixing processes with respect to the evolution of a hydrothermal system. Influx of new (usually less evolved magma) into an existing storage system is also considered an important triggering mechanism for volcanic eruptions (Sparks et al. 1977) and clear evidence for the importance of this process is preserved in many intrusive rocks in SW Japan.

\section{Large area silicic volcanism - Supereruptions and the consolidation of continental crust}

Together with the formation of large batholiths, spatially extensive silicic volcanism is a key process in forming and stabilizing new continental crust, by merging and consolidating accreted terranes and their sedimentary and metamorphic successions (Fig. 1b, 3a,b). Volcanism

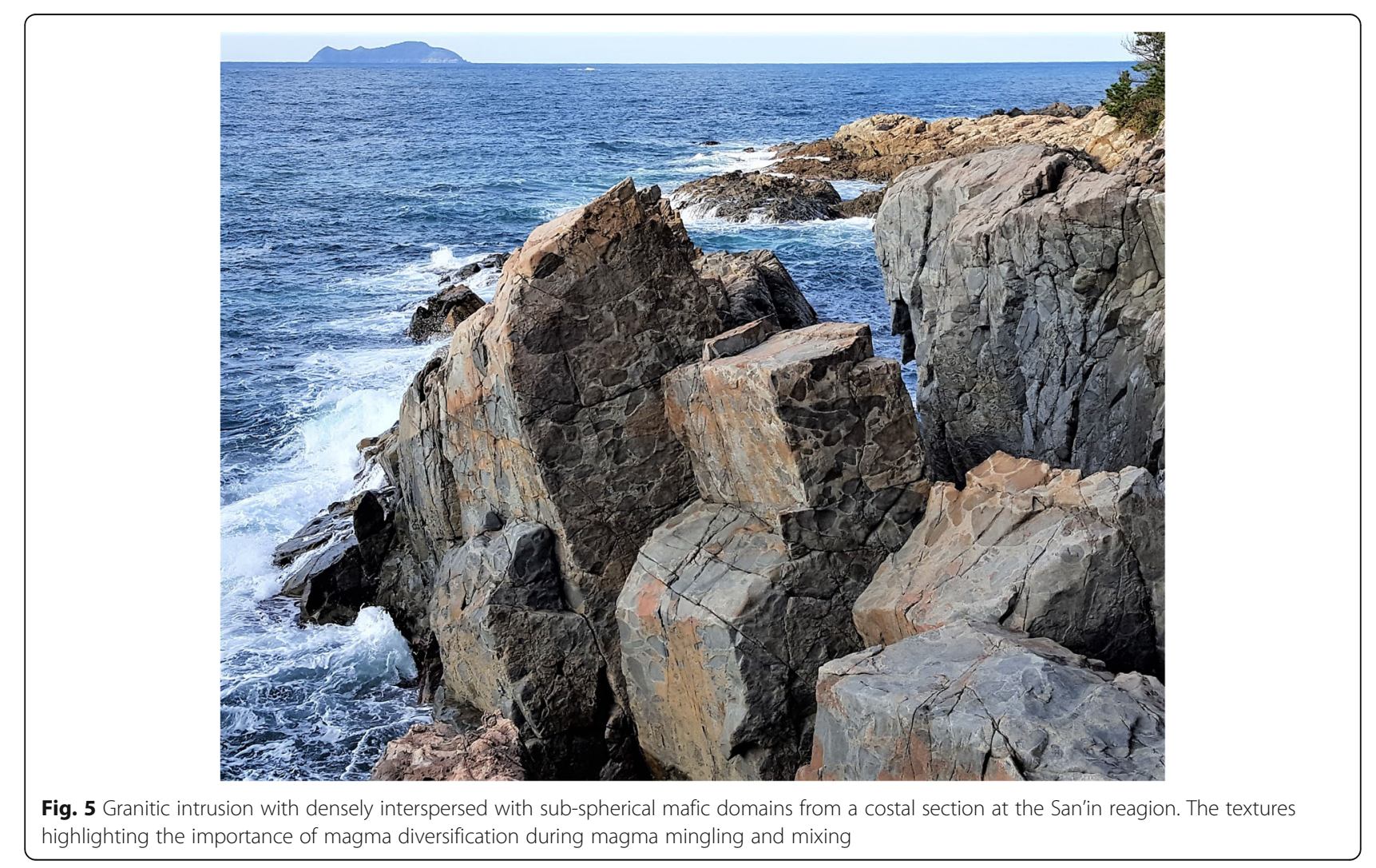


during the continental arc stage produced huge pyroclastic deposits, which ubiquitously are associated with the formation of large collapse calderas. This type of eruption has been recently branded "supereruptions" due to the large amount of material, that is produced during these events (Bachmann and Bergantz 2008; Miller and Wark 2008). Caldera formation is promoted by several factors, many of which apply to the Eastern Asian continental arc during the Cretaceous and early Paleogene, such as: (1) a high convergence rate normal to the trench (Northrup et al. 1995), which will add substantial amounts of basalt to the lower crust of the arc, (2) thick preexisting continental crust, (3) a prolonged duration of arc magmatism. The late Paleogene, rift initiation will also contribute to the formation of large silicic calderas and the tectonic situation during that time has been compared to the modern Taupo Volcanic zone (Cole 1990; Wilson et al. 1995; Imaoka et al. 2011).

At least 14 Paleogene cauldrons have been identified in the San'in region, many of them also associated with co-genetic intrusive rocks. Like the granitic plutons, caldera geometries are exposed at different crustal levels allowing investigation of their geometries and emplacement as well as their collapse mechanism (Murakami et al. 1982; Murakami and Komuro, 1993).

A well studied example is shown in Fig. 6, which shows the stratigraphic succession formed by the Paleogene Sakurae Cauldron (Komuro, H. and Ohtsuka, M. 1999). As typical for many large silicic calderas, more than one collapse event has been identified. The early stage is characterized by overall less evolved successions, the second stage produced very large volumes of monotonous highly welded ignimbrites. Rocks of this stage show abundant highly elongated fiamme suggesting that they underwent non-particulate flowage (rheomorphism) during or after deposition (Komuro et al. 2006) and typical eutaxitic textures in thin section (Fig. 7). Several smaller granitoid stocks intruded the succession after the cataclysmic eruption.

\section{Submarine successions formed during back-arc rifting}

One of the key factors, controlling the characteristics of a volcanic eruption is the environment at which magma reaches the surface (e.g. subaerial vs submarine vs subglacial). With the opening of the Japan Sea, this setting changes now successively from subaerial to lacustrine and finally submarine. One of the most comprehensive stratigraphic records documenting the opening of the Japan Sea is preserved within the Miocene strata of the Shimane Peninsula. Volcanic successions are now alternating with sediment transported into the opening back-arc basin (Kano 1991). Depositional facies changes, recorded in terrigenous sediments, show a seamless transition from lacustrine to an open marine environment during the lower

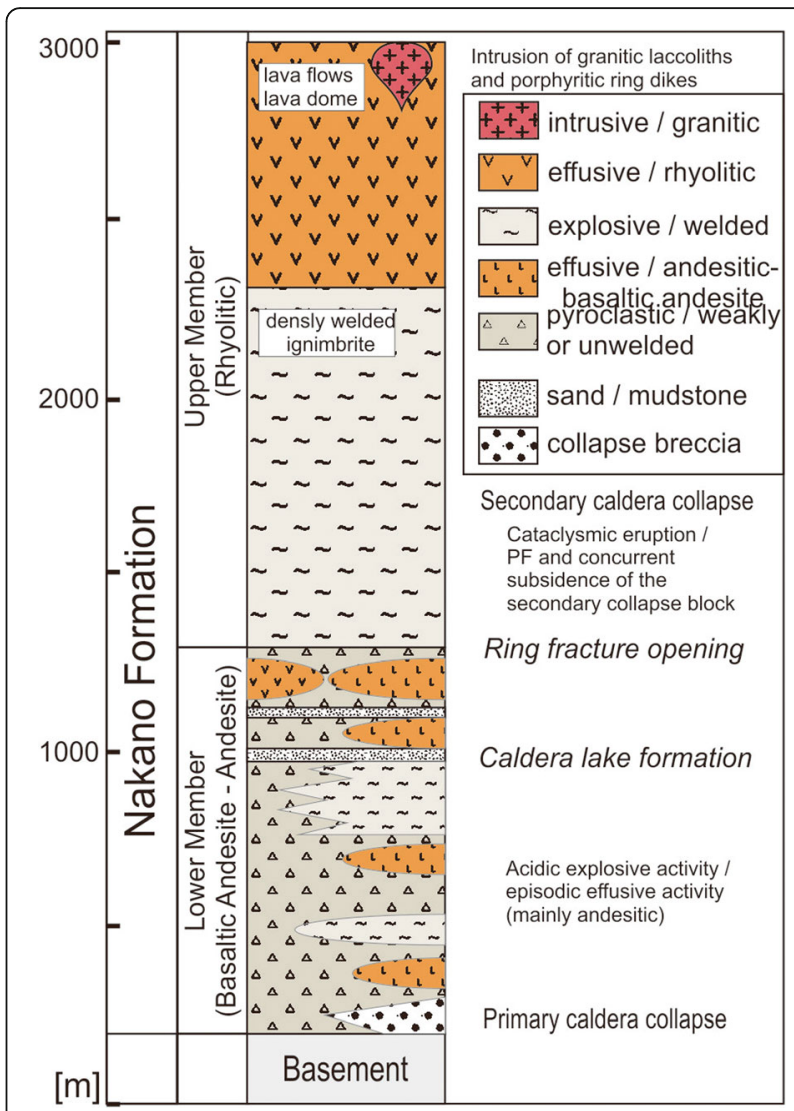

Fig. 6 Simplified stratigraphic section through the Sakurae Cauldron / Nakano Formation (Komuro et al. 2006). Notice the massive, approximately $1 \mathrm{~km}$ thick deposit of highly welded ignimbrites, erupted during the second major caldera collapse

Miocene (Kano 1991; Sakai et al. 2013). Massive (> $20 \mathrm{~m}$ ) deposits, formed by pyroclastic density currents of rhyolitic composition, are intercalated with the clastic sediments in the early Miocene Koura Formation (Fig. 8). Poorly sorted lithic and pumice rich deposits as well as thinly bedded tephra successions are exposed along the eastern shore of Shimane Peninsula (Fig. 9). The depositional environment of pyroclastic rocks in the Koura Formation shows transitional features between subaerial and shallow lacustrine emplacement (Kano 1990). By the end of the lower Miocene environmental conditions changed to fully marine (Josoji Formation, Fig. 8). Remnants of several submarine seamounts are preserved within the subsequent formations. At Etomo (central Shimane Peninsula), rhyolitic lavas and intrusive rocks are covered by a volcaniclastic apron formed from eruption-fed mass flows and reworked pyroclastic material. Based on these outcrops, Kano (1996) presented a model for explosive submarine eruptions. Subaqueous eruption plumes will be affected by the high water pressure and are presumed to collapse quickly, but in the case of silica rich eruptions, part of the ejected material probably segregated into the water column and reached the surface 


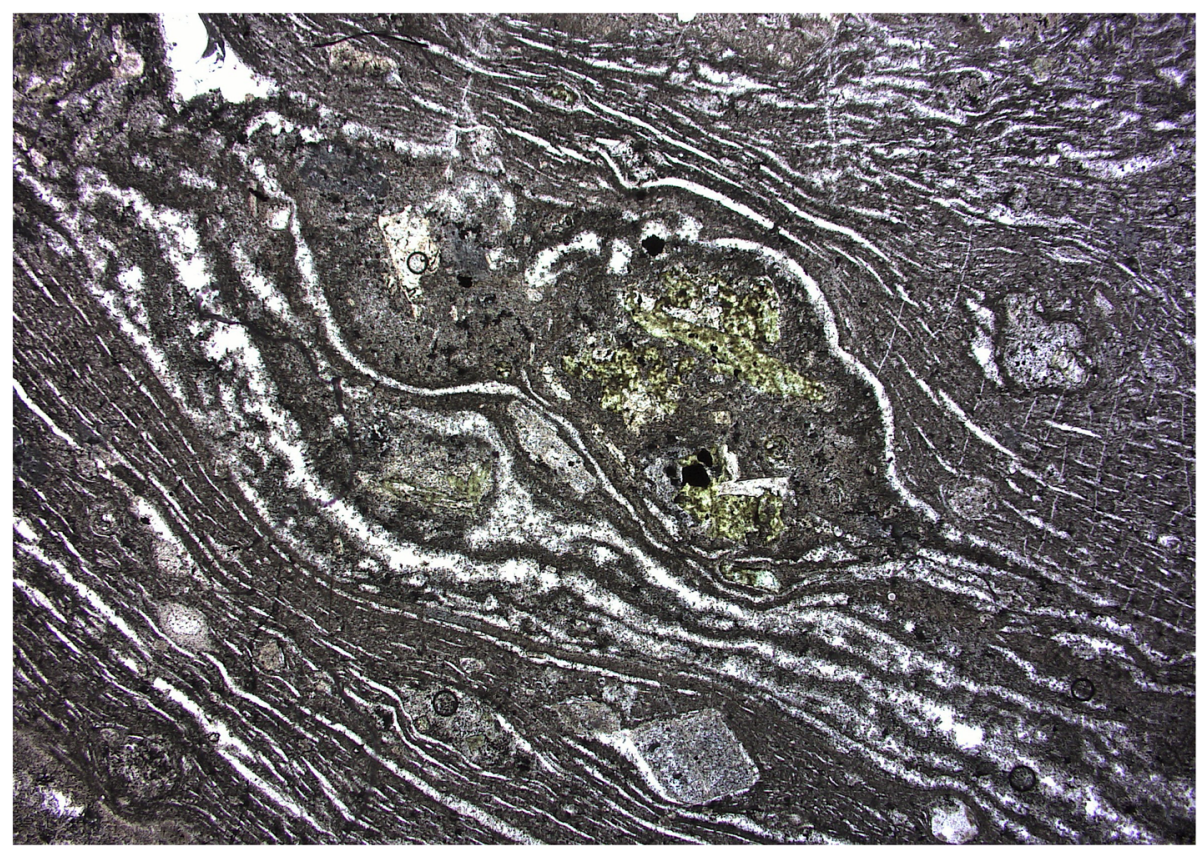

Fig. 7 Thin section, showing an eutaxitic texture from a densely welded pyroclastic flow deposit (upper part in Fig. 6)

where it can accumulate to form large pumice rafts (Allen and McPhie 2000; Jutzeler et al. 2014). Another volcanic edifice is preserved within the Middle Miocene Ushikiri Formation (western Shimane Peninsula). Dominantly rhyolitic effusive activity formed a seamount of evolved composition at water depths between 200 and $1000 \mathrm{~m}$ (Kano et al. 1991).

Correlative to the Furue and Matsue formations are submarine successions of the Takashibiyama Formation (Kano et al. 1993). Basaltic, andesitic and dacitic lavas and pyroclastic rocks form several overlapping eruptive centers. Their subvolcanic feeding systems and large mafic to intermediate shallow magma chambers are also exposed, providing unique insight into different structural levels of a volcanic seamount (Fig. 10).

\section{Monogenetic volcanism in SW Japan}

Monogenetic volcanic fields in SW Japan have been a research target of several petrological studies (paragraph 2.2). In addition a number of specialized studies have investigated mantle petrology for some selected volcanoes where mantle xenoliths occur (Arai et al. 2000) as well as petrogenesis of highly silica undersaturated rocks (Tatsumi et al. 1999).

A monogenetic volcano sensu stricto is a small volcanic edifice, which has erupted only once for a very short duration, after which activity ceases. This term is contrasted with polygenetic volcanoes, which erupt multiple times in the same location, forming large complex volcanic edifices. A wide spectrum exists between these two endmember cases (Németh and Kereszturi 2015). Multiple controls exist (Di Traglia et al. 2009; Cimarelli et al. 2013), that decide which type of activity and evolution a volcanic complex will take and have also been explored with important case studies in SW Japan (Valentine and Connor 2015). A comprehensive comparison between the two endmembers has been provided by Sawada et al. (2009), who directly compared physical and geomorphological as well as compositional features of monogenetic and polygenetic volcanism from Daikonjima Island and $\mathrm{Mt}$ Daisen. Deposits from violent Strombolian eruption from Irao volcano in the Abu volcanic field (SW Japan) have been investigated by Kiyosugi et al. (2014) who demonstrate that monogenetic volcanoes can have complex eruptive histories with simultaneous explosive and effusive activity and changes in eruption style and composition during the course of the eruption. Seismic tomography studies from the Abu volcanic field have investigated spatial and temporal distributions of volcanism with respect to the structure of the crust and distribution of melting anomalies in the mantle (Kiyosugi et al. 2010). Formation of more evolved melts and their respective crustal storage as well as magma mixing has been also investigated (Koyaguchi 1986). All these results highlight the variable and complex factors, which control the respective volcanic landforms, also showing that the (widely used) term monogenetic is often a simplification. Monogenetic volcanism is not restricted to continental settings but also erupted under submarine conditions. A middle Miocene, shallow-marine alkali-basalt tuff cone in described in Kano (Kano 1998). 


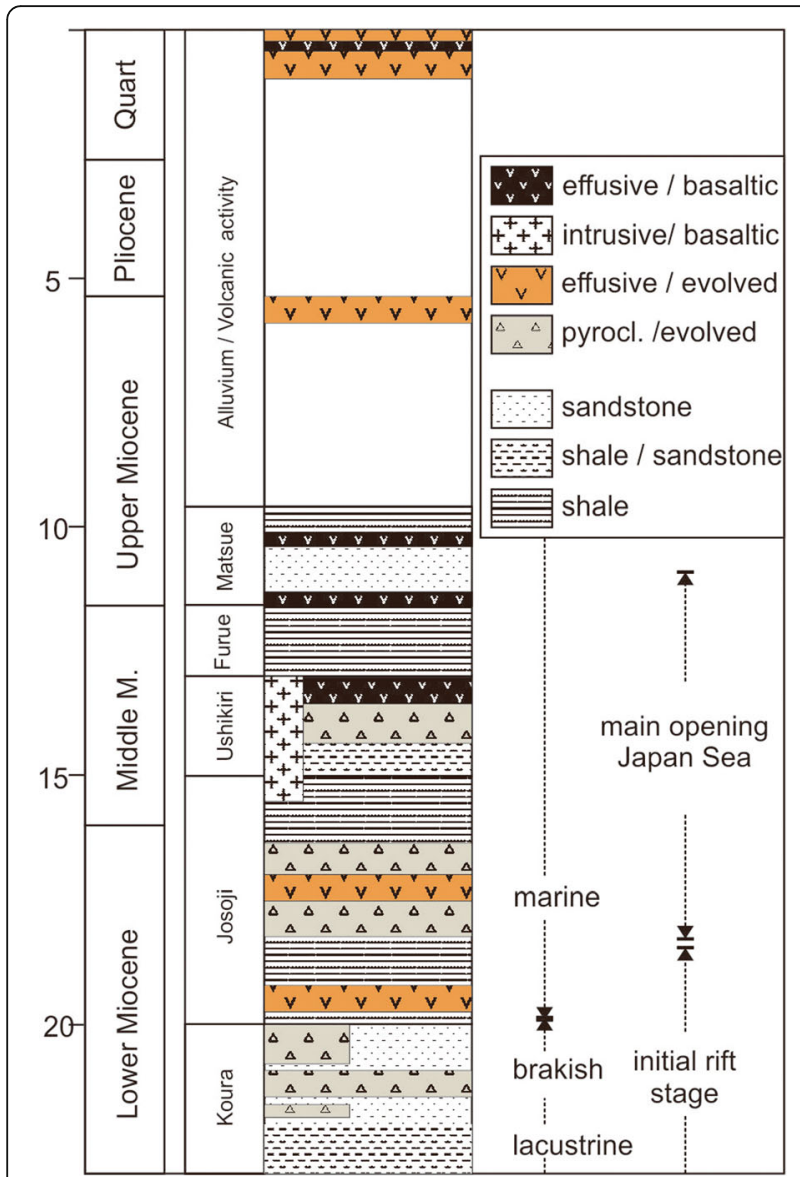

Fig. 8 Relationship between Miocene back-arc strata (Shimane Peninsula / Matsue area) and igneous activity in the back-arc region (Ishiga and Dozen 1997). Rift related submarine pyroclastic and intrusive successions are intercalated with terrigenous sediments. Post rifting activity is marked by monogenetic volcanism (12 Ma recent) and arc volcanism (3 Ma - recent)

Violent interaction of ascending melt and shallow water produces characteristic deposits and typical monogenetic landforms, characterized by explosive, phreatomagmatic activity (see next paragraph).

The Matsue Formation (Fig. 8) and upper Miocene to recent volcanic successions form Oki Island contain a large number of diverse volcanic successions, that are highly complex and often also do not strictly qualify as monogenetic volcanism. Brenna et al. (2015) demonstrated how subvolcanic storage acts as density filter, exerting critical control on the composition and spatial distribution of basaltic and evolved eruptive products on Oki Dozen Island.

The Aonoyama volcanic field (Fig. 3f) marks to onset of evolved adakitic arc magmatism (together with the Stratovolcanoes of Mt Daisen, mt Sanbe and Mt Oetakayama see next paragraph) due to subduction of the Philippine Sea Plate (see paragraph 2.2). Geomorphological features of the Aonoyama volcanic field are distinct from the stratovolcanoes. The field consist of several andesitic - dacitic domes with small eruptive volumes. Several authors have therefore grouped the Aonoyama among the monogenetic volcanic fields (Kumura et al. 2002; Valentine and Connor 2015), despite its evolved adakitic characteristics. Pineda-Velasco et al. (2018) interpret the difference in eruptive volume and style by a reduced magma production rate and slower magma ascent.

\section{Large stratovolcanoes in the san-in region}

The following section discusses general geology and eruptive history of the three most prominent stratovolcanoes in the San'in region, Daisen, Sanbe and Oe-Takayama.

Oe-Takayama is a highly dissected stratovolcano which formed during the late Pliocene to early Pleistocene time. The mountain episodically erupted evolved dacitic lavas which are intercalated with several pyroclastic flow deposits (Kano et al. 2001). During the early Pleistocene the Senyama Cone formed as a separate complex NNE of OeTakayama (Fig. 11). Non - to poorly vesicular juvenile fragments deposited by base surges suggest that magma was fragmented by phreatomagmatic eruptions due to contact with external water. Source of external water was probably a porous media aquifer of well sorted sands close to the coast of the Japan Sea (White 1996). After the initial phreatomagmatic activity, dry eruptions resumed producing mainly block and ash flow deposits (Kano and Takarada 2007). Subsequent development of a hydrothermal system within the Senyama complex lead to intense alteration of the primary pyroclastic deposits and formation of a silver bearing hydrothermal deposit (Zeng et al. 2010).

$M t$. Sanbe is a large quaternary stratovolcano, which has produced a large variety of effusive and pyroclastic deposits throughout its history (Matsui, 1971). Eruptive activity at Mt Sanbe has been subdivided into two stages. The first one lasting from 1.4 to $1.0 \mathrm{Ma}$ and the second stage from 0.5 Ma to recent times (Pineda-Velasco et al., 2018). Eruptions of the first stage are contemporaneous with activity at Oe-Takayama approximately $20 \mathrm{~km}$ ESE from Sanbe. During the second stage, activity is limited to Mt Sanbe, while Oe-Takayama was already experiencing substantial erosion during that time. Explosive activity at Sanbe starts with a number of Plinian dispersal tephras, with the first one (Kisuki pumice) being the largest (Fig. 12). The second stage of Plinian activity (Unnan Pumice) was accompanied by the formation of a small Caldera of approximately $5 \mathrm{~km}$ in diameter. Subsequent mainly Pelean activity produced several lava domes which formed the modern edifice of Mt Sanbe (Matsui 1971; Hattori et al. 1983).

Mt Daisen is the largest stratovolcanoe in the San'in region (Fig. 13). Activity began with several dome forming eruptions in the Hiruzen complex SE of the modern edifice subsequently shifting to the NE. A large number 


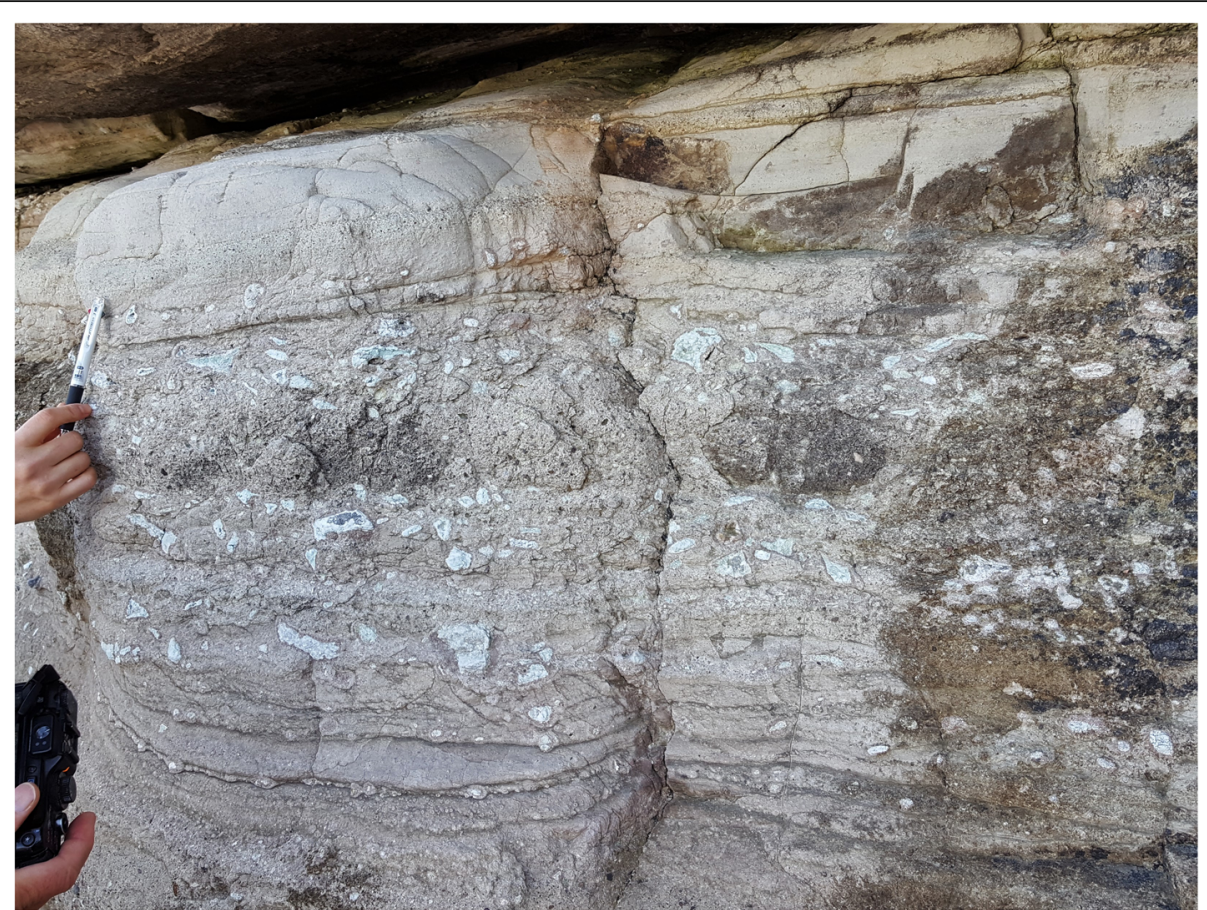

Fig. 9 Deposits from a pyroclastic density current of the lower Miocene Koura formation. Notice abundant armored lapilli in the basal part of the section, a vaguely stratified pumice rich central part and several fining upward subsets in the topmost part (pencil-tip)

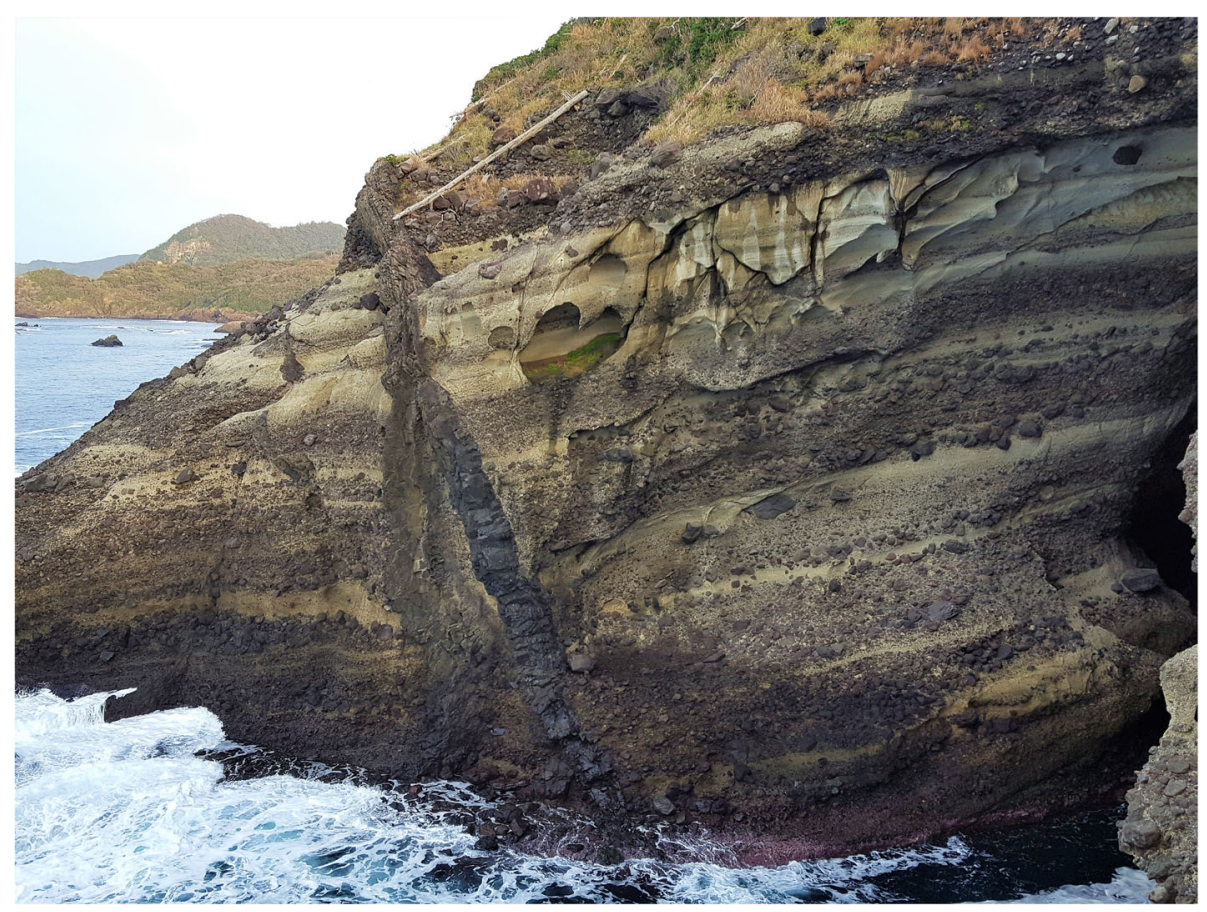

Fig. 10 Late Miocene deposits of the Takashibiyama formation at Cape Kukedo, central Shimane Peninsula, showing a cross section through the pyroclastic successions of a submarine seamount. A steeply dipping dike is crosscutting the volcaniclastic units 

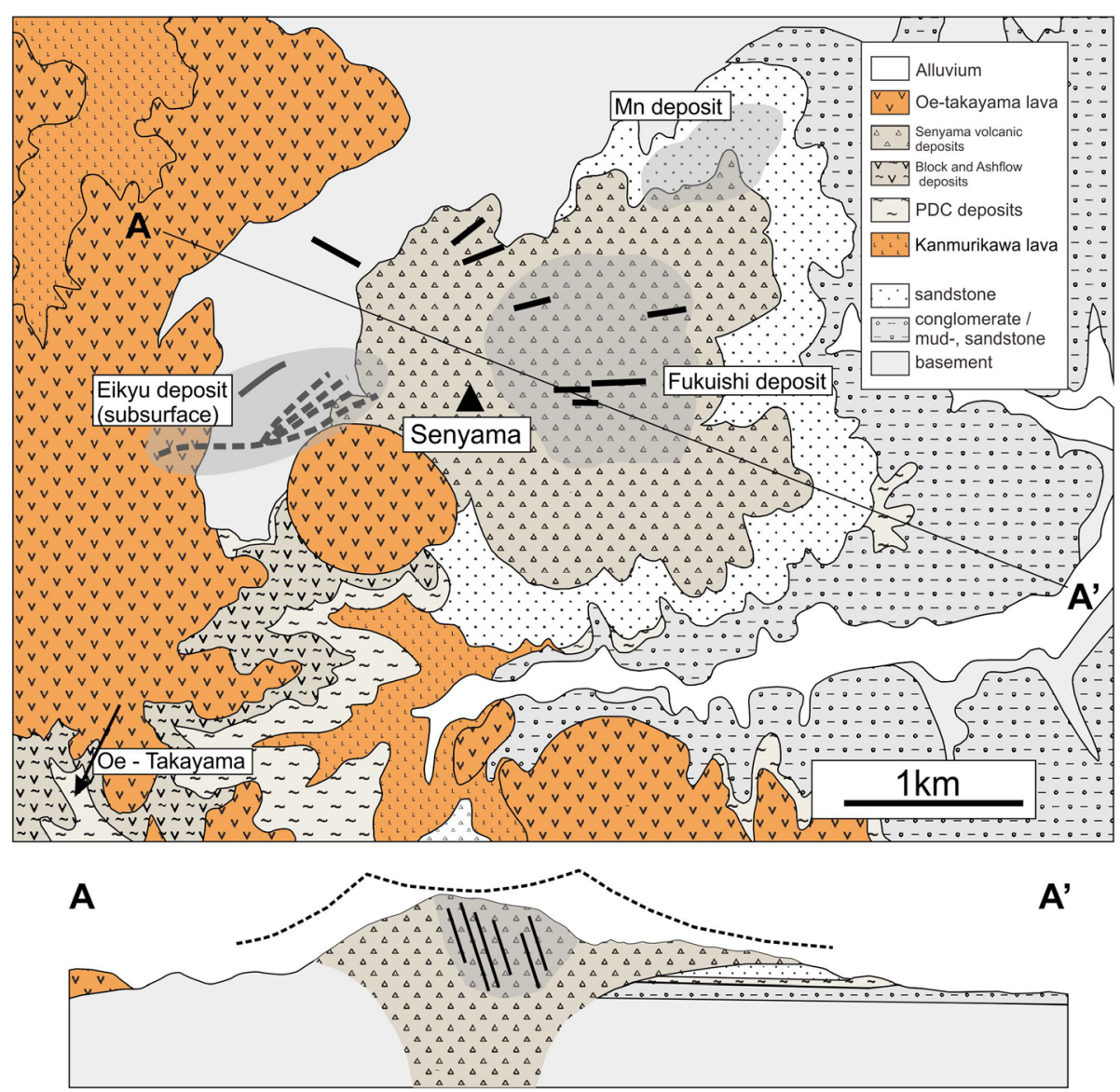

Fig. 11 Geological map and profile of the Senyama mountain (simplified after Kano, 2007). Senyama is a satellite cone of the larger O'eTakayama, the oldest adakitic stratovolcanoe in the area. Senyama is notable for it's rich silver occurrence which was mined during medieval times. Silver mineralization is associated with post-eruptive hydrothermal activity and alteration in the volcanic complex

of Plinian eruptions (Fig. 12) and intermittent dome forming eruptions produced the modern Daisen-Hiruzen volcanic complex (Tsukui 1985; Kimura et al. 2005b; Yamamoto 2017). The tectonic and igneous evolution and the respective volcanic activity of the SW Japan arc segment is summarized in Fig. 14 highlighting important stages during the evolution of the arc from Cretaceous to recent times.

\section{Volcanic hazards}

Many volcanic phenomena can't be studied by direct observation, simply because they are too dangerous and also often destructive to even the most resilient automated analytical equipment. However, much information about volcanic hazards can be obtained from studying the distribution and properties of the respective deposit and erupted materials. The following section gives a brief summary of the different volcanic hazards and - where available - with special reference to specific field sites and examples in Japan.

\section{Hazards from fallout tephra and ballistically ejected material}

Explosive volcanic eruptions can inject large amounts of fragmented material (tephra) and gas into the atmosphere. The dispersal of the erupted pyroclastic material depends on a number of factors such as the style of the eruption, height of the volcanic plume, grain size distribution of the ejected material as well as the prevailing wind direction (Bonadonna et al., 2015). Several hazards are related to fallout tephra. The eruption of Asama volcano in 1783 (Tenmei eruption - NE Japan arc) was recorded in an ancient annotated painting (Fig. 15) that describes some of the immediate effects from fallout tephra during a large eruption:

" ... fireballs were scattered over a large area, and burning ash came down and accumulated like snow ...".

Ash fall during explosive eruptions poses a large spectrum of hazards to humans, environment as well as 


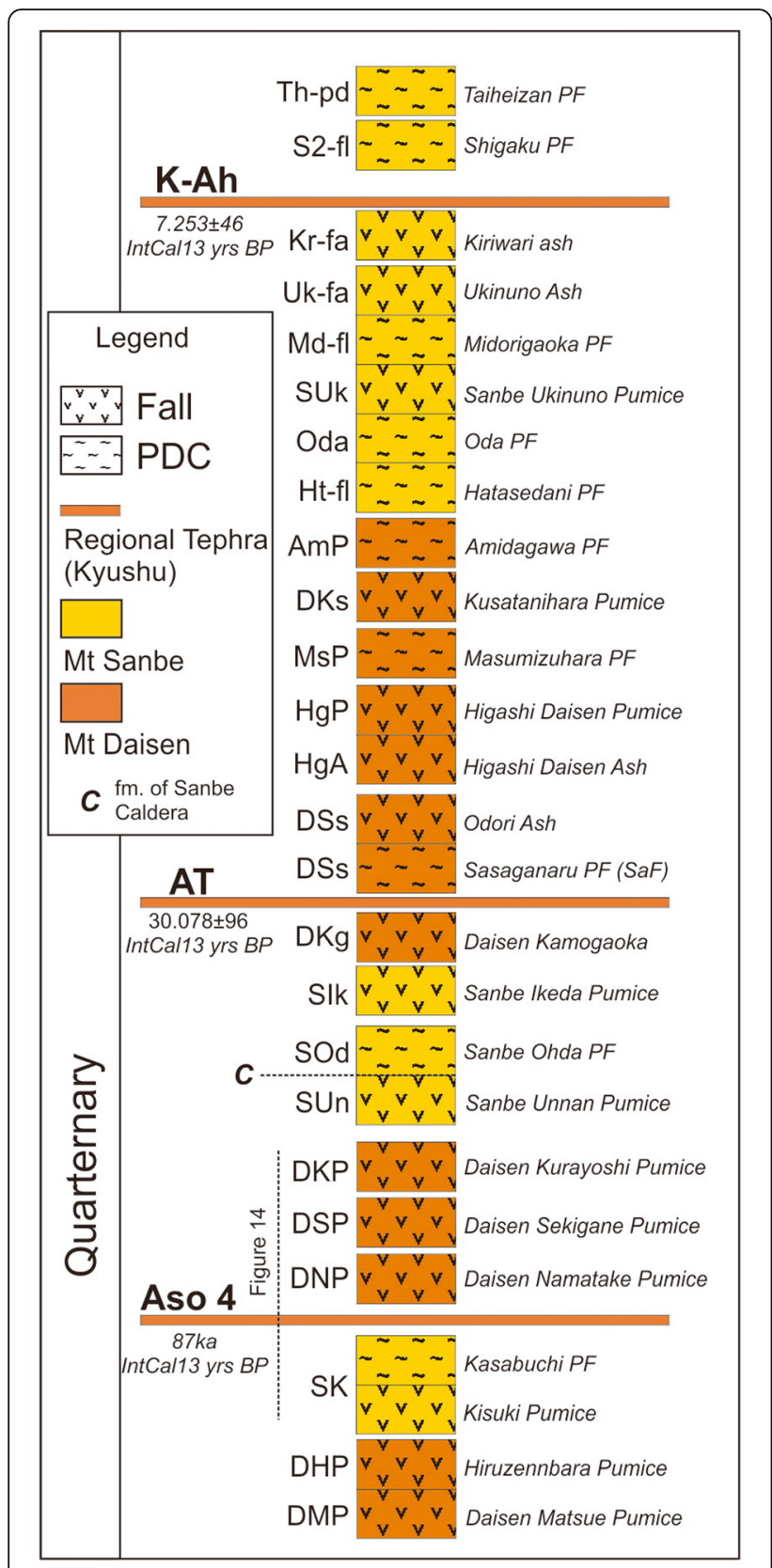

Fig. 12 Combined stratigraphic record from Daisen and Sanbe Volcano showing major tephras and large deposits formed by pyroclastic density currents (Albert et al. 2018)

infrastructure and aviation. In the immediate vicinity of a volcano thick accumulation of tephra (Fig. 16) poses hazards due to collapsing roofs but also causes respiratory health risks (Baxter et al. 2014). In some cases, volcanic gases and aerosols can be produced in immediately lethal amounts during an eruption (Kling et al. 1987), but also during long-term exposure at a lower dose (Hansell and Oppenheimer 2004) and not only affect humans but also livestock, crops and wild plants. Volcanic ash also poses a serious threat to aircrafts because it can induce failure in jet engines and abrade aircraft parts and surfaces (Prata and Rose 2015). An universal volcanic alert level system for aviation exists which was developed, coordinated by the International Civil Aviation Organization, a UN specialist agency together with national Volcano Observatories.

\section{Hazards from lava flows}

Lava flows, produced during effusive volcanic eruptions can show highly variable behavior in terms of flow velocity, aspect ratio and size of the area covered. The single most important factor controlling this behavior is their chemical composition, silica content in particular. Mafic lava flows with low silica content (ca. up to 55\%) are characterized by low viscosity and can flow and spread out rapidly from their source. Felsic, more silica rich lava flows show much higher viscosities and spread more slowly and not as far from their source (Peterson and Tilling 2000).

In May 2018, a new eruptive episode (lower Puna eruption) began at the East Rift Zone of Kilauea volcano on the island of Hawaii. Within a few month, the eruption covered more than $35 \mathrm{~km}^{2}$ of land with basaltic lava flows (USGS 2018). During this time, hundreds of houses were destroyed, and a number of people were injured. Casualties from effusive eruptions are usually small compared to those from explosive eruptions but the loss of property can be substantial (Tedesco et al. 2007). A notable exception is the eruption of Mount Nyiragongo in the Democratic Republic of the Congo in 1977 where a lava lake drained from the summit of the over $3000 \mathrm{~m}$ high volcano. Fast lava flows caused a large number of casualties in adjacent villages (Favalli et al. 2009). The particularly low viscosity of the lava from this volcano, a Nepheline Melilithe, is related to its chemical composition with a particularly low silica contend. The ca. $6 \mathrm{Ma}$ old Melilite-Olivine Nephelinite from Hamada, SW Japan, produced lavas of similar composition, which erupted within the San'in region during the monogenetic stage (see above).

Many historic examples exist, where villages or entire townships were threatened and partly destroyed by lava flows such as the city of Catania at the eastern slopes of Mt Etna (Branca et al. 2013). Another example is the Laki fissure eruption from 1783 in Iceland, which erupted ca $15 \mathrm{~km}^{3}$ basaltic lava from a ca $27 \mathrm{~km}$ long vent system (Thordarson and Self 1993). A large number of villages was destroyed during the eruption, which also caused a famine due to loss of cops and animals. Additional hazards from lava flows arise when they interact with the environment such as water or vegetation. Lava flows entering rivers, lakes or the ocean or flowing over snow or glaciers, can cause powerful steam explosions (see also below), which pose a substantial hazard due to 


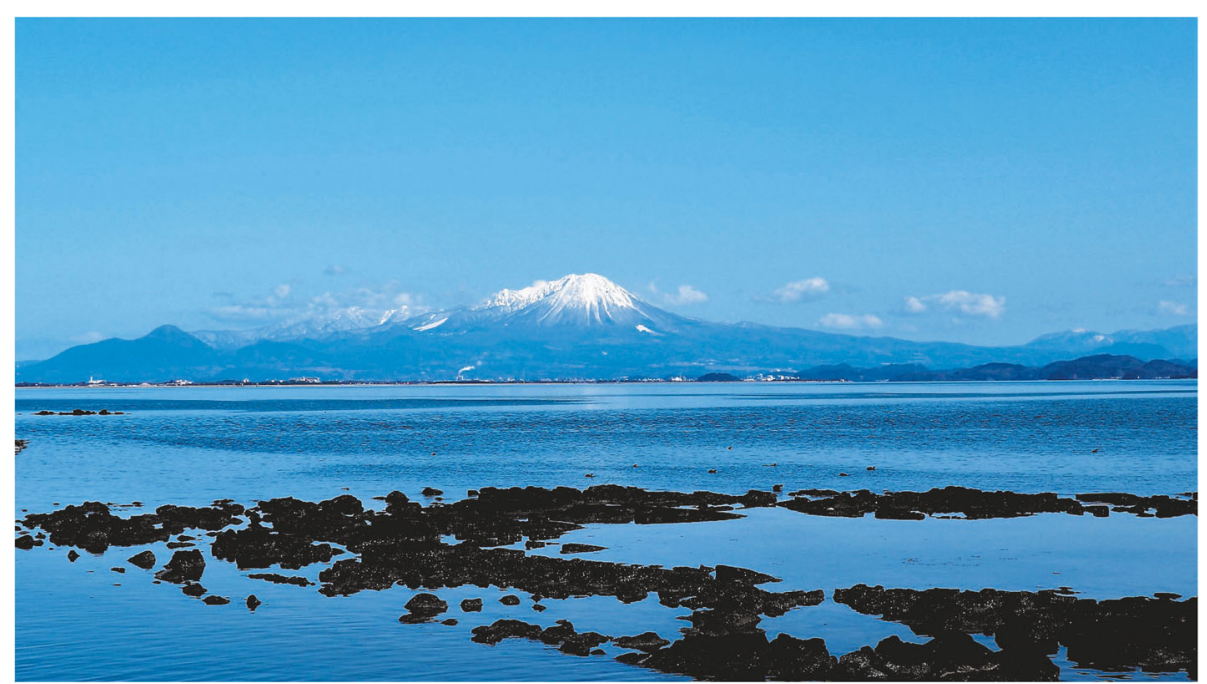

Fig. 13 Mt Daisen is the largest stratovolcano in the SW-Japan arc. The snow-capped summit in the foreground is build up of several lava domes, which have been the source of a large number of block and ash flows, their deposits now found in the pyroclastic apron of the young complex. The sub-circular structure in the foreground is a lava blister, belonging to the basaltic lava flows of Daikonjima island, a contemporary monogenetic volcano of the young arc

the erratic nature of these explosions (Todesco 2017). In addition, large amounts of meltwater can be formed during subglacial eruptions which may drain instantaneously in glacier outburst floods (also sometimes called by their Icelandic term jökulhlaup - see below).

Lava flows of more evolved composition are generally characterized by much higher viscosities and lower flow velocities. They usually spread less and travel shorter distances. With respect to the area covered, their edifices are much higher (higher aspect ratios) in comparison with their mafic counterparts (Auer et al. 2018), and thus usually only pose a hazard in the direct vicinity of the volcano. In many cases, silicic effusive eruptions will not form lava flows at all, but only lava domes which grow either from within due to the addition of lava into the dome complex (endogenic growth) or due to the addition of individual lava lobes to an existing complex (exogenic growth). A well documented example is the growth of the Showa Shinzan lava dome in Hokkaido, observed by the postmaster Masao Mimatsu (Mimatsu 1962), who documented the grow of a large new dome over many month.

Substantial effusive activity of mainly basaltic volcanism is widespread within the San'in region (see previous paragraph) and, although no longer active, young volcanic successions from Daikonjima Island, the DaitoYokota and Abu volcanic fields provide instructive field examples of effusive volcanic activity (Figs. 13, 17). Additional examples for lava dome structures and silica rich lava flows are found at the large stratovolcanoes of Mt. Daisen and Mt. Sanbe.

\section{Hazards from pyroclastic density currents (PDC)}

Pyroclastic density currents are fast moving mixtures of hot gas and pyroclastic material (Branney et al. 2002; Sulpizio et al. 2014). Different names have been used to describe these currents in the past (e.g. nuée ardentes, pyroclastic flow or pyroclastic surge), due to a wide variability of the phenomena as well as characteristics of the deposits. The term PDC has become the most general name summarizing a large spectrum of highly hazardous phenomena (Cole et al. 2015). Deposit volumes vary considerably between less than $0.001 \mathrm{~km}^{3}$ to more than $1000 \mathrm{~km}^{3}$ and several mechanisms are known which can generate PDC (Dufek et al. 2015). The most important ones are: (1) Directed blasts - This type was first recognized during the initial phase of the eruption of Mt St Helens in 1980, when the eruption started with the collapse of the northern flank of the volcano generating a debris avalanche. This collapse rapidly decompressed a partially crystalline magmatic body (cryptodome) within the volcanic edifice, generating a lateral blast that expanded horizontally to the north and overtook the landslide that initially triggered the eruption (Druitt 1992). (2) Boiling over - this type is genereated, when vesiculated magma is frothing or fountaining over the crater rim without forming a convective plume. Currents subsequently travel down the slopes under the act of gravity (Rader et al. 2015). (3) Dome collapse - Frequent formation of PDC is associated with Pelean type volcanic activity. These eruptions are characterized by the formation of highly instable lava domes in the summit region of the volcano. Partial or complete collapse of the dome 


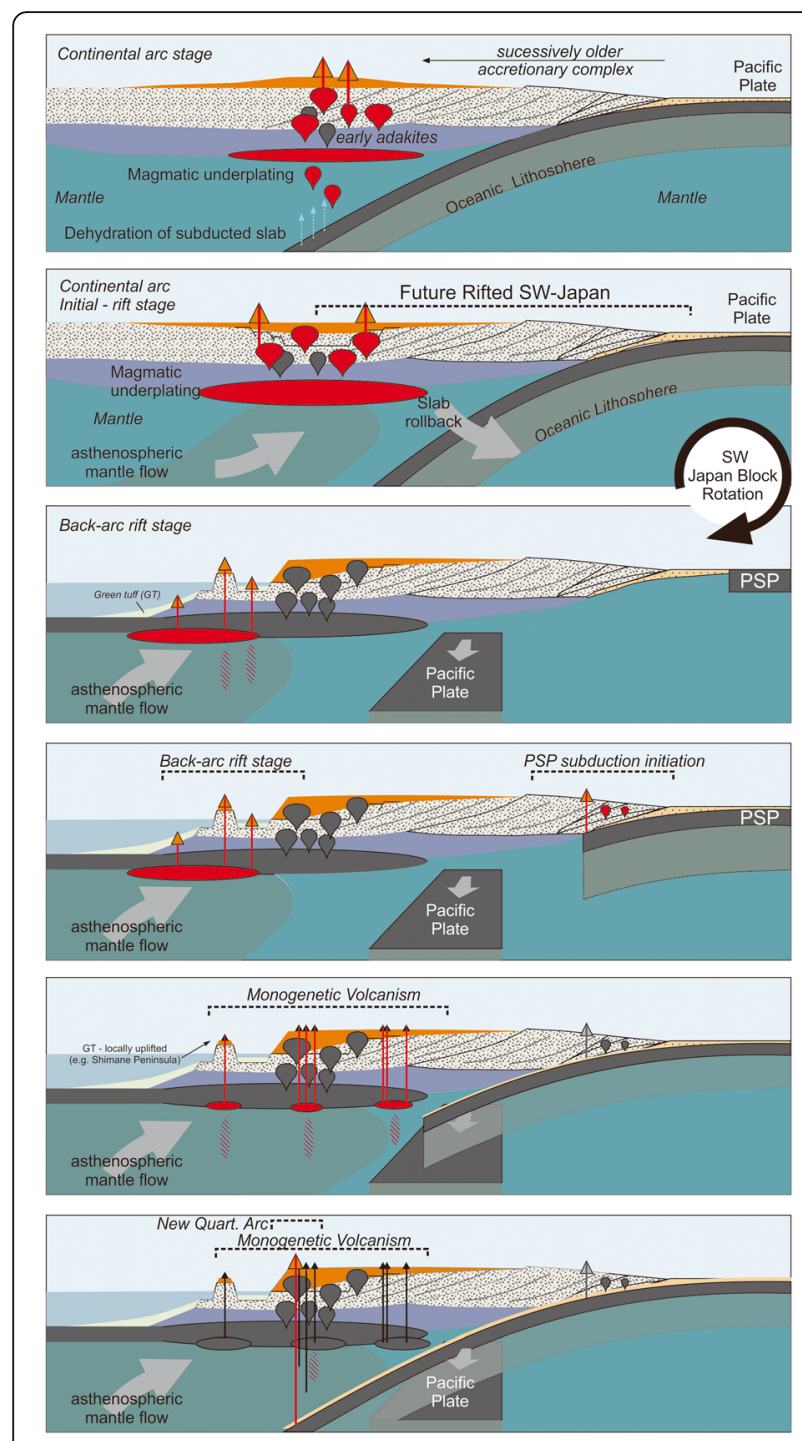

Fig. 14 Synopsis of the tectonic and igneous evolution in the SW Japan arc

structure generates currents of hot gas and a mixture of pyroclastic particles from ash size to large blocks up to several meters in diameter, known as block and ash flow. Depending on the morphology of the mountain, propagation direction of block and ash flows are often confined to one sector of the volcano at a time, although this may change during the course of an eruption. Examples of recent volcanic activity which generated block and ash flows are the eruption of Mt Unzen between 1990 and 1995 (Ui et al. 1999) and the recent activity of Merapi (Charbonnier and Gertisser 2008).

(4) Eruption column collapse - Explosive volcanic activity often forms eruption columns of variable height forming a volcanic plume. Depending on a variety of (often unknown) factors such as vent radius, eruption velocity, particle mass fraction and size, entrainment of atmospheric air, the eruption plume with remain buoyant or collapse. Eruption column collapse is yet another important mechanism to generate pyroclastic density currents (Dufek et al. 2015). Depending on the style and size of eruption (e.g. unsteady Vulcanian vs steady Plinian), deposits can show highly variable volumes and also a large range of features (Sparks and Wilson 1976; Druitt et al. 2002). Unlike block and ash flows which are often unidirectional with hazards confined to a specific area, PDC from eruption column collapse will impose a hazard to all sectors around the mountain. In addition PDC's can also form during phreatomagmatic and phreatic eruptions (see below)

\section{PDC's from Mt Daisen and Mt Sanbe}

The modern summit regions of $\mathrm{Mt}$ Daisen and $\mathrm{Mt}$ Sanbe are characterized by several large lava dome complexes. While active, these lava domes have generated a large number of block and ash flow deposits which are preserved in many locations around both mountains (Kusano and Nakayama 1999; Kimura et al. 2005b). Some initial flow units show thinly bedded a thin layer of tar at the base, when overriding vegetation, attesting to the high temperature of the flow (Sawada et al. 2000). Several flow units indicate episodic collapse of the growing dome producing valley fill (shoestring) deposit with flat or gently dipping upper surfaces. Reverse graded bedding is common in many of the deposits with large blocks accumulating close to the top of individual bedsets (Fig. 18). In addition, many of these flow units show weakly stratified lower subsets with low angle cross stratification, indicating emplacement by dilute pyroclastic density currents (pyroclastic surges).

Pyroclastic density currents formed during collapse of large Plinian eruption columns have also been identified at Mt Sanbe. Particular devastating events of this type occur during large caldera forming eruptions. The respective pumice rich deposits which can cover large areas with pyroclastic deposits several meters thick are known as ignimbrites and may be loose and unconsolidated (Fig. 19) or highly welded (Fig. 7). The eruption of the Unnan tephra at Mt Sanbe was accompanied by the formation of a small collapse caldera. Extensive ignimbrites are preserved in the vicinity of the Volcano to the southeast and also in the area of Oda city at the coast of the Japan sea (Fig. 19).

\section{Hazards from Phreatomagmatic eruptions and phreatic explosions}

Ascending magma can interact with meteoric water, either in subsurface aquifers (see the Senyama example in the previous paragraph) or with surface water. Under certain conditions, Molten Fuel Coolant Interaction (MFCI) can cause strong thermohydraulic explosions (Büttner et al. 2002), even for magmas which would otherwise erupt 


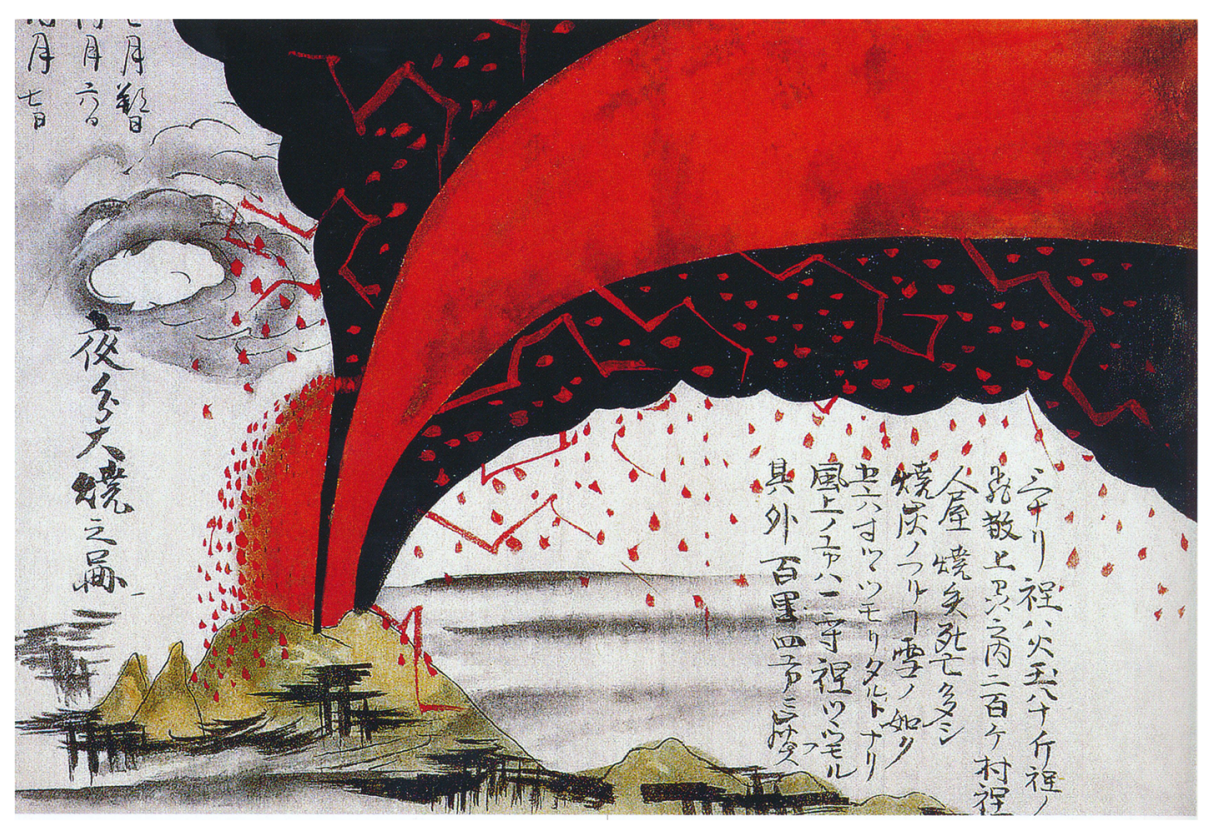

Fig. 15 Historical drawing of the great eruption of Asama volcano in 1783 (Tenmei eruption - NE Japan arc). The annotations give a vivid description of the associated hazards and the scale of the disaster that occurred during this eruption

quietly and effusive (i.e. without external water). The respective eruptions are called phreatomagmatic eruptions and pose a substantial hazard due to ballistic ejection of large blocks in the vicinity of the volcano. In addition, phreatomagmatic eruptions can also generate PDC (base surges) which pose hazards in a much larger area around the volcano. Phreatomagmatic eruptions are typically associated with monogenetic volcanism (Schmincke 1977; White 1996), especially in humid regions, but can also occur on stratovolcanoes, especially in the presence of glaciers or crater lakes as well as in sub-lacustrine (Belousov and Belousova 2001) and shallow marine settings. Deposits from Phreatomagmatic eruptions have been identified at Oe-Takayama (Kano and Takarada 2007) but also from deposits erupted during the Monogenetic stage (see above). In some cases, explosive volcanic activity can occur without the direct involvement of magma (Rosi et al. 2018). These explosions can form due to a variety of mechanisms (Houghton et al. 2015) for example when a magmatic system is heating meteoric water (without directly interacting) but also form explosions in hydrothermal systems. Like the phreatomagmatic eruptions, phreatic explosions pose a substantial hazard due to ballistic ejection and formation of pyroclastic density currents. An additional complication arises in the fact that some of these events often discernible precursors in the monitoring record (sometimes called "blue sky eruptions"). One of the biggest volcanic disasters in recent times was caused by such an eruption at Ontake, central Honshu (Maeno et al. 2016).

\section{Lahars}

The word lahar is an Indonesian term for debris flows or hyperconcentrated flows in volcanic areas (the terms "volcanic mudflow" or "debris flow" are also frequently found in the literature). There are several ways to form lahars, for example melting of snow or glacial ice during emplacement of hot effusive or explosive material in the summit region of a volcano, intense rainfall on tephra deposits, as well as breakout floods or ejection of water from crater lakes (Graettinger et al. 2010). Their dynamics are complex and controlled by the sediment water ratio, grain size distribution, temperature, flow velocity, clay mineral content and the morphology of the local terrain (Pierson et al. 1987). Volcanic areas are particularly prone to these events due to the ready availability of abundant loose pyroclastic material and lahars count among the most deadly volcanic phenomena (Voight 1990). Lahars are an ubiquitous phenomena for many Volcanoes in Japan and even very small eruptions such as the phreatomagmatic eruption of Mt Usu in 2000 (Fig. 20) and the phreatic eruption of Mt Ontake in 2014 generated lahars (Kataoka et al. 2018). Formation of lahars is not always caused by an ongoing volcanic eruption. Instead, many lahars are triggered by earthquakes or heavy rainfalls between eruptions which makes them particularly unpredictable (Miyabuchi et al. 2015). Lahar deposits are known from Mt Sanbe (Fukuoka and Matsui 2002) and include the famous site of the Sanbe-Azukihara Buried Forest. 

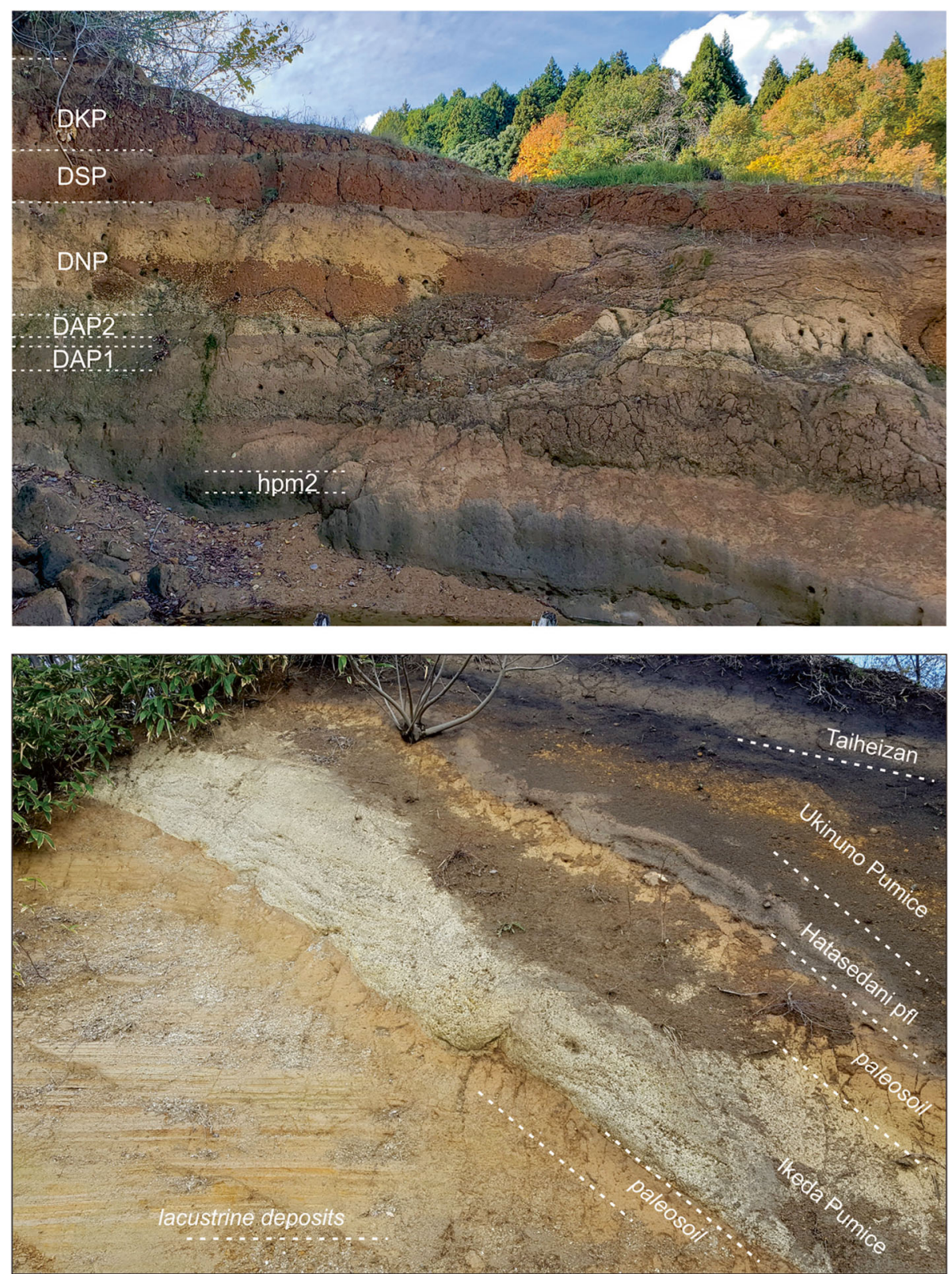

Fig. 16 Two representative outcrops, showing the field occurrence of tephras at Daisen (top) and Sanbe (bottom) volcano (for stratigraphic position, refer to Fig. 12)

\section{Volcanic tsunamis}

Volcanic activity can generate tsunamis in the world's oceans and several historical records of such events exist from Japan. One of the largest volcanic disasters in the history of the country was caused by the flank collapse of Mount Unzen's Mayuyama dome in 1792 (Sassa et al. 2016). The landslide and a subsequently generated tsunami caused an estimated 15.000 casualties (Fig. 21). A more recent example of such a disaster is the almost complete destruction of Anak Krakatoa, Indonesia in 2018. The event follows the famous eruption (and tsunami) of the original Krakatoa volcano in 1883 and was already anticipated due to the instable positioning of the edifice on the rim of the caldera (Giachetti et al. 2012). Several mass wasting deposits have been identified in the submarine successions of the Shimane Peninsula (see previous paragraph). Comparison with recent examples is difficult due to limited exposure of modern deposits although some recent documentations exist (Watt et al. 2015). It remains open whether some of the events forming these deposits were accompanied by the 


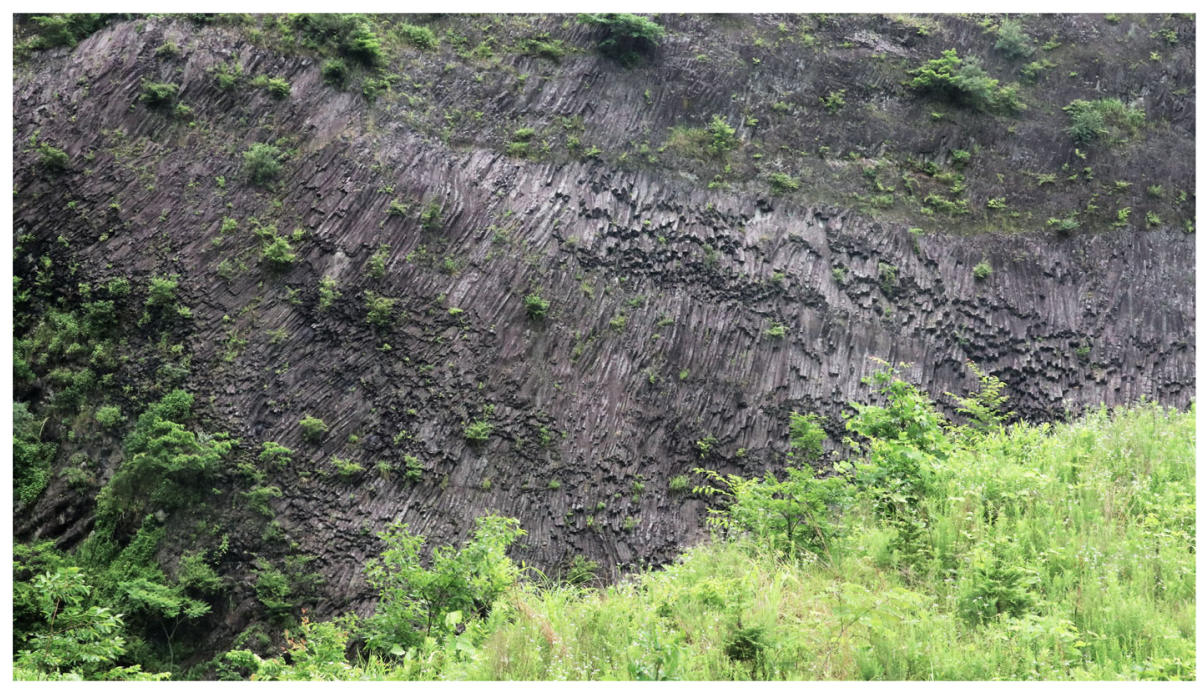

Fig. 17 Extensive outcrop of basaltic lava in the Yokota area, a monogenetic volcanic field ESE of Mt Daisen. Several subsets of saucer-shaped columnar jointed basalts suggest infilling of a large lava lake at this location

generation of tsunamis, although this possibility has recently been proposed for some (non-volcanic) submarine deposits (Yamamoto et al. 2007).

\section{Conclusion}

Southwest Japan contains an almost unparalleled variety of interesting volcanic successions, including a broad range of different volcanic landforms, which show a large assortment of interesting subaerial deposits, as well as excellent examples of diverse types of submarine volcanism. Different styles of volcanic activity can be observed within the framework of the longtime tectonic evolution of the area and the resulting change in the igneous-tectonic associations. With

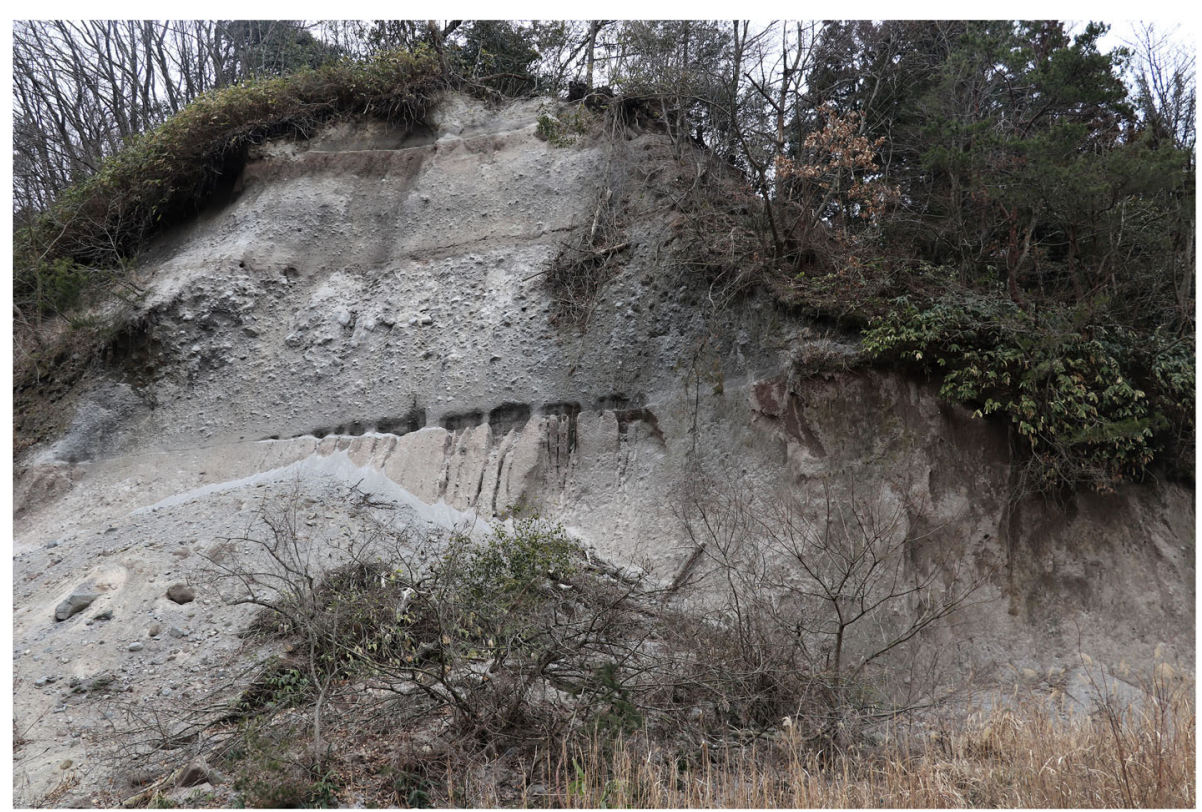

Fig. 18 Several flow units from the Taiheizan block and ash flow form Sanbe volcano, exposed by a recent landslide. Contemporary ash fall deposits can be seen in Fig. 16 (lower image, uppermost unit). The deposit is located approximately $2.5 \mathrm{~km}$ south from the presumed locality of the active lava dome and has been originally emplaced with a valley fill areal distribution, but now remains only as isolated bars in the several valleys around the mountain 

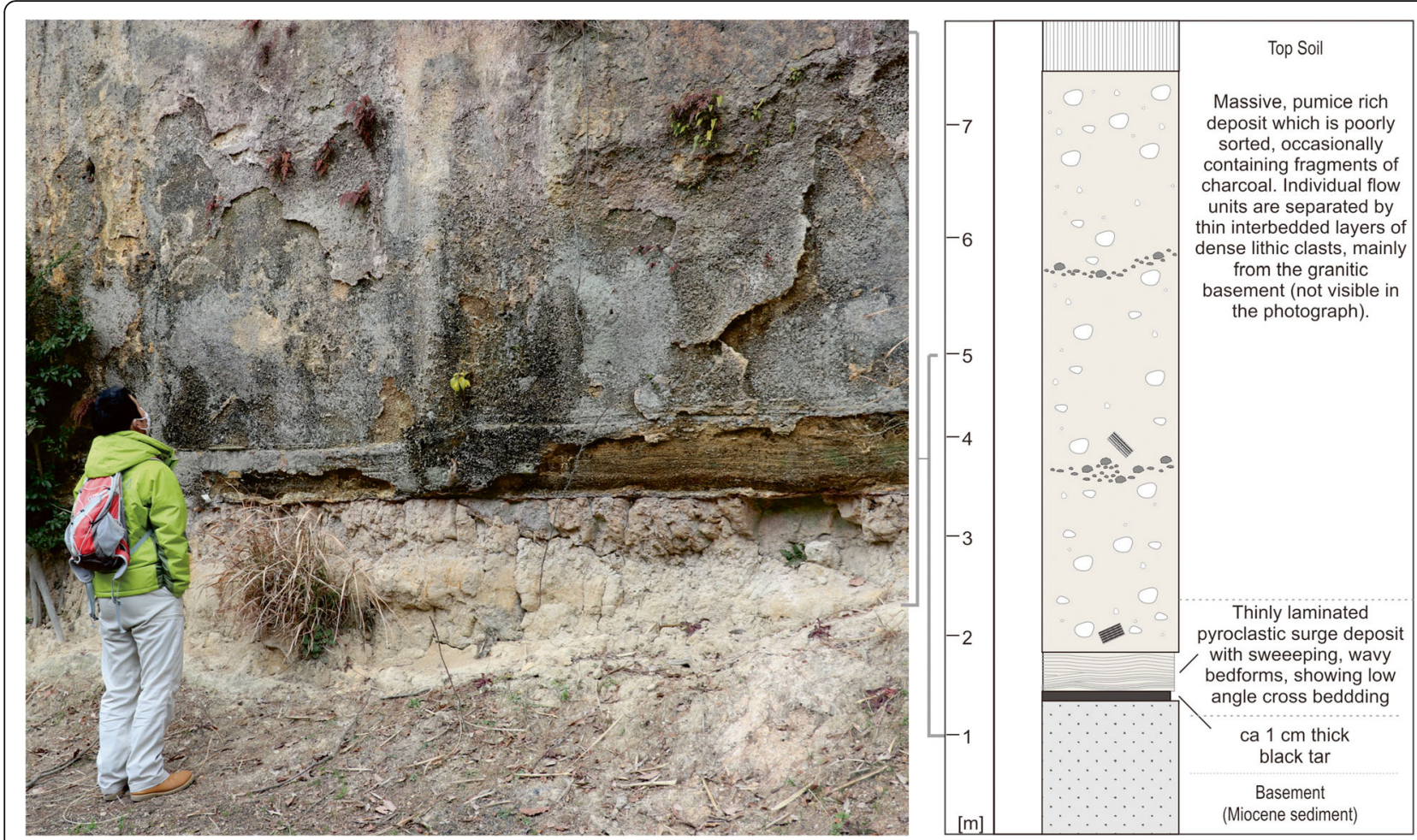

Fig. 19 Approximately $7 \mathrm{~m}$ thick massive pyroclastic flow deposit from Sanbe volcano ca. $15 \mathrm{~km}$ away from the source. The deposit is associated with the formation of a small collapse caldera, ca. $5 \mathrm{~km}$ in diameter

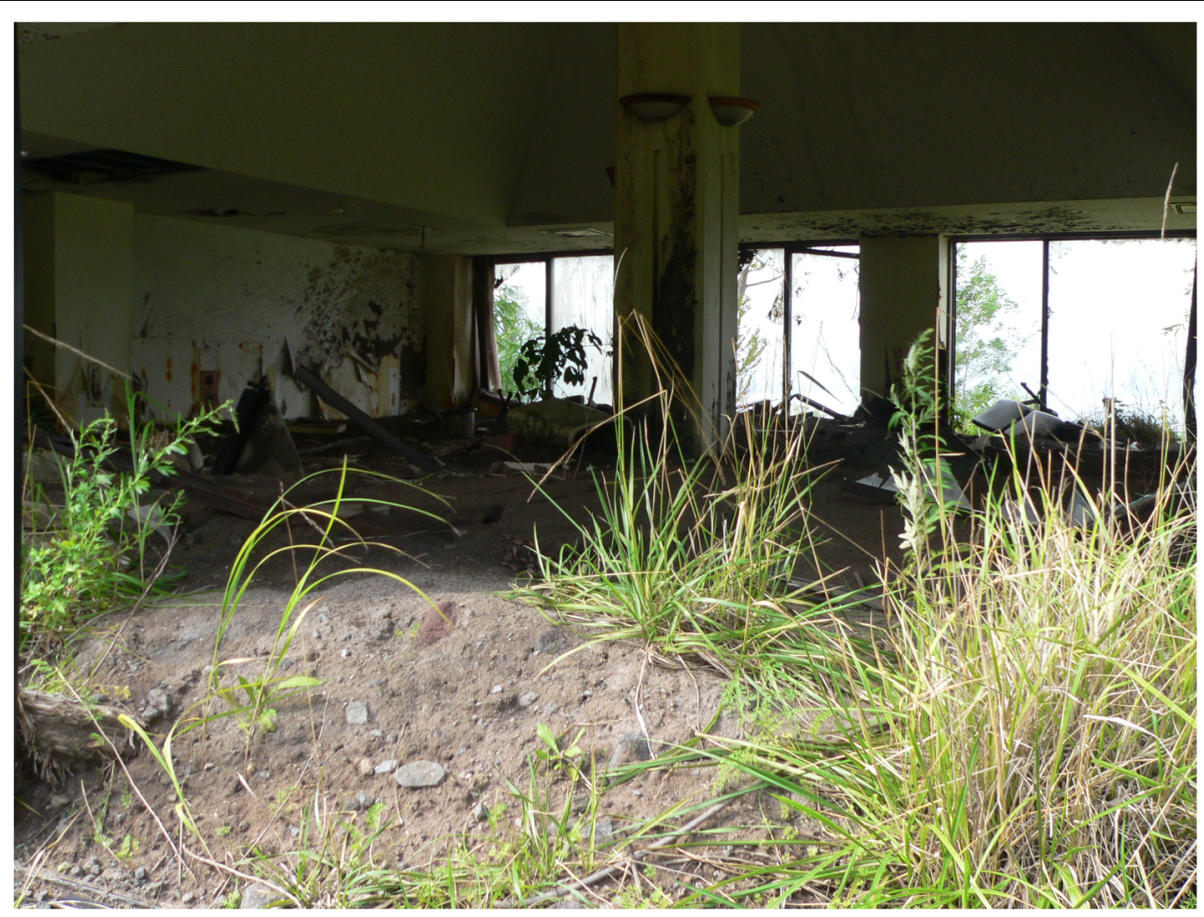

Fig. 20 Lahar deposit emplaced within a residential area at Mt Usu, Hokkaido in 2000. While this eruption caused extensive damage to houses and infrastructure, it caused no human casualties, due to close monitoring of the volcano and efficient hazard mitigation efforts 


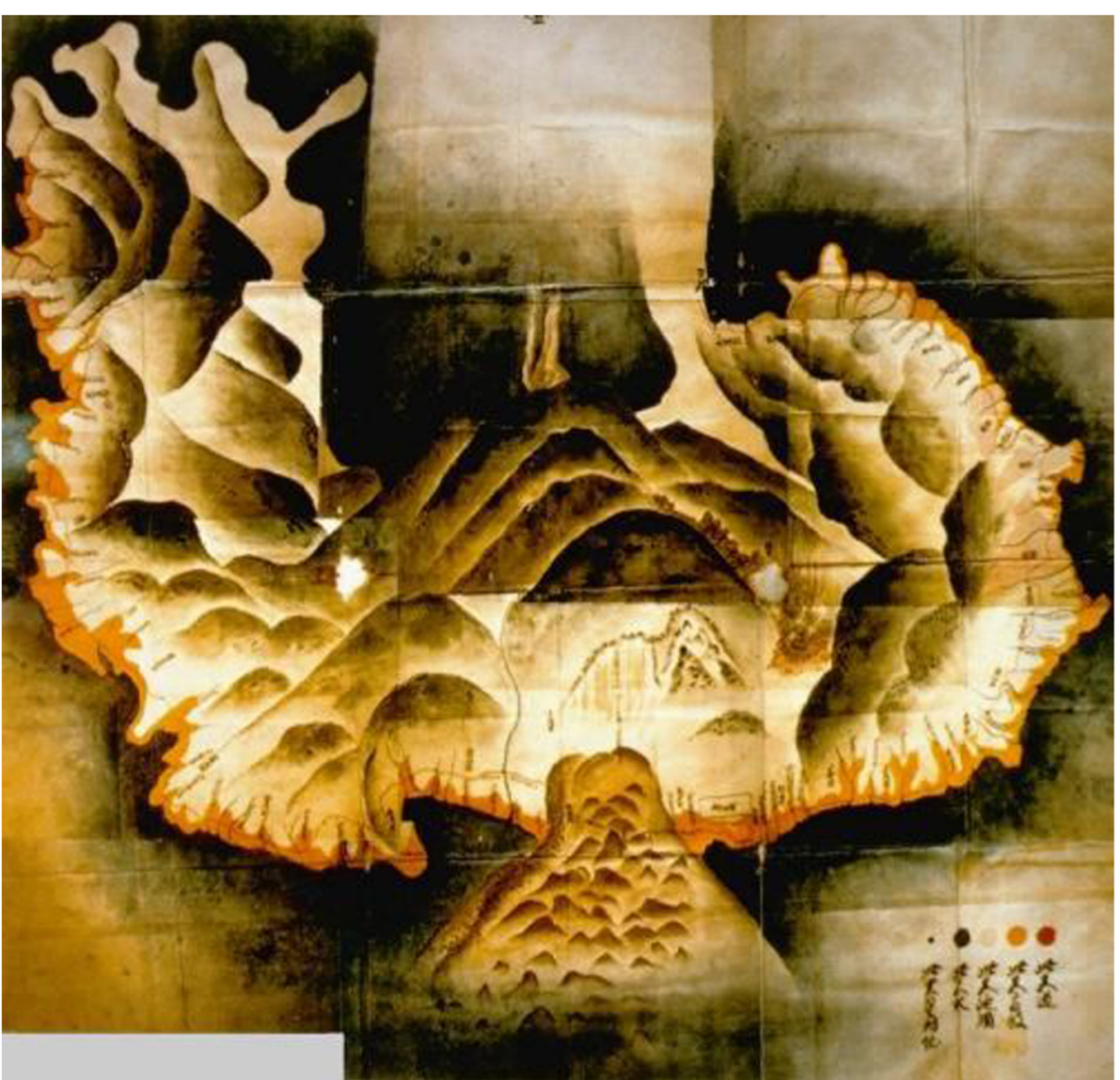

Fig. 21 Map of the Shimabara Peninsula, showing Unzen volcano and the Mayuyama debris avalanche. Upon entering the sea, the landslide created a tsunami which caused about 15,000 human casualties along the coastline (Global Volcanism Program)

the geological background, provided in this work, students pursuing an interest in volcanism and the associated volcanic hazards will find a rich and interesting field area in the San'in region. The area already contributed much to our understanding of arc magmatism and will hopefully also improve our understanding of volcanic hazards due to its excellent display of igneous and pyroclastic successions.

\section{Abbreviations}

BTL: Butsuzo Tectonic Line; HMA: High magnesium andesites; MFCl: Molten Fuel Coolant Interaction; MTL: Median Tectonic Line; PDC: Pyroclastic density currents; PSP: Philippine Sea Plate

\section{Acknowledgements}

The author thanks Kazuhiko Kano and Paul Morris for helpful comments on an earlier draft of the manuscript. Federico Di Traglia and an anonymous reviewer are also thanked for constructive comments and suggestions.

\section{Authors' contributions}

No other author had a role in writing of the manuscript. The author read and approved the final manuscript.

\section{Funding}

Sponsors or funding agency have no contribution to this review.

Availability of data and materials

Not Applicable

\section{Competing interests}

The authors declare that they have no competing interests.

Received: 11 March 2019 Accepted: 2 October 2019

Published online: 10 December 2019

\section{References}

Albert, P.G., V.C. Smith, T. Suzuki, et al. 2018. Constraints on the frequency and dispersal of explosive eruptions at Sambe and Daisen volcanoes (south-West Japan arc) from the distal Lake Suigetsu record (SG06 core). Earth-Sci Rev 185 1004-1028.

Allen, S.R., and J. McPhie. 2000. Water-settling and resedimentation of submarine rhyolitic pumice at Yali, eastern Aegean, Greece. J Volcanol Geotherm Res 95: 285-307.

Arai, S., H. Hirai, and K. Uto. 2000. Mantle peridotite xenoliths from the Southwest Japan arc: A model for the sub-arc upper mantle structure and composition of the Western Pacific rim. J Mineral Petrol Sci 95: 9-23.

Auer, A., A. Belousov, and M. Belousova. 2018. Deposits, petrology and mechanism of the 2010-2013 eruption of Kizimen volcano in Kamchatka, Russia. Bull Volcanol 80: 33.

Auer, A., C.E. Martin, J.M. Palin, et al. 2015. The evolution of hydrous magmas in the Tongariro volcanic Centre: The 10 ka Pahoka-Mangamate eruptions. N Z Geol Geophys 58: 364-384. https://doi.org/10.1080/00288306.2015.1089913.

Auer, A., J.D.L. White, and M.J. Tobin. 2016. Variable $\mathrm{H} 2 \mathrm{O}$ content in magmas from the Tongariro volcanic Centre and its relation to crustal storage and magma ascent. J Volcanol Geotherm Res 325: 203-210. https://doi.org/10. 1016/j.jvolgeores.2016.06.021.

Bachmann, O., and G. Bergantz. 2008. The magma reservoirs that feed supereruptions. Elements 4: 17-21. 
Bachmann, O., and G.W. Bergantz. 2004. On the origin of crystal-poor rhyolites: Extracted from batholithic crystal mushes. J Petrol 45: 1565-1582.

Baxter, P.J., A.S. Searl, H.A. Cowie, et al. 2014. Evaluating the respiratory health risks of volcanic ash at the eruption of the Soufriere Hills volcano, Montserrat, 1995 to 2010. Geol Soc Lond Mem 39: 407-425.

Belousov, A., and M. Belousova. 2001. Eruptive process, effects and deposits of the 1996 and the ancient basaltic phreatomagmatic eruptions in Karymskoye lake, Kamchatka, Russia. Volcaniclastic Sediment Lacustrine Settings 30: 235-260.

Berz, G., W. Kron, T. Loster, et al. 2001. World map of natural hazards-a global view of the distribution and intensity of significant exposures. Nat Hazards 23: 443-465.

Bonadonna C, Costa A, Folch A, Koyaguchi T (2015) Tephra dispersal and sedimentation. In: The Encyclopedia of Volcanoes. Elsevier, pp 587-597.

Branca, S., E. De Beni, and C. Proietti. 2013. The large and destructive 1669 AD eruption at Etna volcano: Reconstruction of the lava flow field evolution and effusion rate trend. Bull Volcanol 75: 694.

Branney MJ, Kokelaar P, Kokelaar BP (2002) Pyroclastic density currents and the sedimentation of ignimbrites. Geological Society of London.

Brenna, M., S. Nakada, D. Miura, et al. 2015. A trachyte-syenite core within a basaltic nest: Filtering of primitive injections by a multi-stage magma plumbing system (Oki-Dōzen, south-West Japan). Contrib Mineral Petrol 170: 22. https://doi.org/10.1007/s00410-015-1181-0.

Browne, B.L., J.C. Eichelberger, L.C. Patino, et al. 2006. Magma mingling as indicated by texture and $\mathrm{Sr} / \mathrm{Ba}$ ratios of plagioclase phenocrysts from Unzen volcano, SW Japan. J Volcanol Geotherm Res 154: 103-116. https://doi.org/10. 1016/j.jvolgeores.2005.09.022.

Büttner R, Dellino P, La Volpe L, et al (2002) Thermohydraulic explosions in phreatomagmatic eruptions as evidenced by the comparison between pyroclasts and products from Molten Fuel Coolant Interaction experiments. J Geophys Res Solid Earth 107:ECV-5.

Cashman KV, Sparks RSJ, Blundy JD (2017) Vertically extensive and unstable magmatic systems: A unified view of igneous processes. Science 355 eaag3055.

Chappell, B.W., and A.J.R. White. 1992. I- and S-type granites in the Lachlan Fold Belt. Earth Environ Sci Trans R Soc Edinb 83: 1-26. https://doi.org/10.1017/ S0263593300007720.

Charbonnier, S.J., and R. Gertisser. 2008. Field observations and surface characteristics of pristine block-and-ash flow deposits from the 2006 eruption of Merapi volcano, Java, Indonesia. J Volcanol Geotherm Res 177: 971-982.

Cimarelli, C., F. Di Traglia, D. De Rita, and D.G. Torrente. 2013. Space-time evolution of monogenetic volcanism in the mafic Garrotxa volcanic field (NE Iberian Peninsula). Bull Volcanol 75: 758.

Cole, J.W. 1990. Structural control and origin of volcanism in the Taupo volcanic zone, new-Zealand. Bull Volcanol 52: 445-459. https://doi.org/10.1007/ bf00268925.

Cole, P.D., A. Neri, and P.J. Baxter. 2015. Hazards from pyroclastic density currents, 943-956. In: The Encyclopedia of Volcanoes. Elsevier.

Czamanske, G.K., S. Ishihara, and S.A. Atkin. 1981. Chemistry of rock-forming minerals of the cretaceous-Paleocene batholith in southwestern Japan and implications for magma genesis. J Geophys Res Solid Earth 86: 10431-10469.

Defant, M.J., and M.S. Drummond. 1990. Derivation of some modern arc magmas by melting of young subducted lithosphere. Nature 347: 662

Di Traglia, F., C. Cimarelli, D. De Rita, and D.G. Torrente. 2009. Changing eruptive styles in basaltic explosive volcanism: Examples from Croscat complex scoria cone Garrotxa volcanic field (NE Iberian Peninsula). J Volcanol Geotherm Res 180: 89-109.

Domeier M, Shephard GE, Jakob J, et al (2017) Intraoceanic subduction spanned the Pacific in the late cretaceous-Paleocene. Sci Adv 3:eaao2303.

Druitt, T.H. 1992. Emplacement of the 18 may 1980 lateral blast deposit ENE of Mount St. Helens, Washington. Bull Volcanol 54: 554-572.

Druitt, T.H., S.R. Young, B. Baptie, et al. 2002. Episodes of cyclic Vulcanian explosive activity with fountain collapse at Soufrière Hills volcano, Montserrat. Mem-Geol Soc Lond 21: 281-306.

Dufek, J., T.E. Ongaro, and O. Roche. 2015. Pyroclastic density currents: Processes and models, 617-629. In: The encyclopedia of volcanoes. Elsevier.

Eichelberger, J.C. 1975. Origin of andesite and dacite - evidence of mixing at glass mountain in California and at other circum-pacific volcanos. Geol SoC Am Bull 86: 1381-1391.

Endo S, Mizukami T, Wallis SR, et al. (2015) Orthopyroxene-rich Rocks from the Sanbagawa Belt (SW Japan): Fluid-Rock Interaction in the Forearc SlabMantle Wedge Interface. J Petrol 56:1113-1137.
Favalli, M., G.D. Chirico, P. Papale, et al. 2009. Lava flow hazard at Nyiragongo volcano, DRC. Bull Volcanol 71: 363-374.

Fukuoka T, Matsui S (2002) Stratigrapy of pyroclastic deposits post-dating the AT tephra, Sanbe Volcano. Earth Sci Chikyu Kagaku 56:105-122.

Giachetti, T., R. Paris, K. Kelfoun, and B. Ontowirjo. 2012. Tsunami hazard related to a flank collapse of Anak Krakatau volcano, Sunda Strait, Indonesia. Geol Soc Lond Spec Pub/ 361: 79-90.

Global Volcanism Program | Educational Resources | Types and Processes Gallery - Volcanic Landslides. https://volcano.si.edu/learn_galleries.cfm?p=14. Accessed 20 Jul 2019

Graettinger, A.H., V. Manville, and R.M. Briggs. 2010. Depositional record of historic lahars in the upper Whangaehu Valley, Mt. Ruapehu, New Zealand: Implications for trigger mechanisms, flow dynamics and lahar hazards. Bull Volcanol 72: 279-296

Hansell, A., and C. Oppenheimer. 2004. Health hazards from volcanic gases: A systematic literature review. Arch Environ Health Int J 59: 628-639.

Hasegawa, A., K. Yoshida, and T. Okada. 2011. Nearly complete stress drop in the 2011 M w 9.0 off the Pacific coast of Tohoku earthquake. Earth Planets Space 63: 35.

Hattori, H., K. Kano, T. Suzuki, et al. 1983. Geology of the Sambesan district. Geol Surv Jpn Quadrang Ser Okayama 12: 68.

Houghton, B., J.D. White, and A.R. Van Eaton. 2015. Phreatomagmatic and related eruption styles, 537-552. In: The Encyclopedia of Volcanoes. Elsevier.

Imaoka, T., K. Kiminami, K. Nishida, et al. 2011. K-Ar age and geochemistry of the SW Japan Paleogene cauldron cluster: Implications for Eocene-Oligocene thermo-tectonic reactivation. J Asian Earth Sci 40: 509-533.

Imaoka, T., K. Nakashima, A. Kamei, et al. 2014a. Episodic magmatism at 105 ma in the Kinki district, SW Japan: Petrogenesis of Nb-rich lamprophyres and adakites, and geodynamic implications. Lithos 184: 105-131.

Imaoka, T., K. Nakashima, A. Kamei, et al. 2014b. Anatomy of the cretaceous Hobenzan pluton, SW Japan: Internal structure of a small zoned pluton, and its genesis. Lithos 208: 81-103.

Ingle, C. 1992. Subsidence of the Japan Sea: Stratigraphic evidence from ODP sites and onshore sections, 1-197. In: Proc ODP Sci Results.

Irvine, T.N.J., and W.R.A. Baragar. 1971. A guide to the chemical classification of the common volcanic rocks. Can J Earth Sci 8: 523-548.

Ishiga, H., and K. Dozen. 1997. Geochemical indications of provenance change as recorded in Miocene shales: Opening of the Japan Sea, San'in region, Southwest Japan. Mar Geol 144: 211-228.

Ishihara, S. 1977. The magnetite-series and ilmenite-series granitic rocks. Min Geol 27: 293-305.

Ishihara, S., and K. Tani. 2004. Magma mingling/mixing vs. magmatic fractionation: Geneses of the Shirakawa Mo-mineralized granitoids, Central Japan. Resour Geol 54: 373-382.

Jolivet, L., K. Tamaki, and M. Fournier. 1994. Japan Sea, opening history and mechanism: A synthesis. J Geophys Res Solid Earth 99: 22237-22259.

Jutzeler, M., R. Marsh, R.J. Carey, et al. 2014. On the fate of pumice rafts formed during the 2012 Havre submarine eruption. Nat Commun 5: 3660.

Kahl, M., S. Chakraborty, F. Costa, et al. 2013. Compositionally zoned crystals and real-time degassing data reveal changes in magma transfer dynamics during the 2006 summit eruptive episodes of Mt. Etna Bull Volcanol 75: 692.

Kamei, A. 2004. An adakitic pluton on Kyushu Island, Southwest Japan arc. J Asian Earth Sci 24: 43-58.

Kamei, A., M. Owada, T. Nagao, and K. Shiraki. 2004. High-mg diorites derived from sanukitic HMA magmas, Kyushu Island, Southwest Japan arc: Evidence from clinopyroxene and whole rock compositions. Lithos 75: 359-371.

Kano, K. 1990. An ash-flow tuff emplaced in shallow water, Early Miocene koura formation, Southwest Japan. J Volcanol Geotherm Res 40: 1-9.

Kano, K. 1991. Volcaniclastic sedimentation in a shallow-water marginal basin: The Early Miocene koura formation, SW Japan. Sediment Geol 74: 309-321.

Kano, K. 1996. A Miocene coarse volcaniclastic mass-flow deposit in the Shimane peninsula, SW Japan: Product of a deep submarine eruption? Bull Volcanol 58: 131-143.

Kano, K. 1998. A shallow-marine alkali-basalt tuff cone in the middle Miocene Jinzai formation, Izumo, SW Japan. J Volcanol Geotherm Res 87: $173-191$

Kano, K. 2018. Stratigraphic framework of the green tuff successions in Japan with reference to the associated geologic events. J Geol Soc Jpn 124: 781803. https://doi.org/10.5575/geosoc.2018.0047.

Kano, K., and S. Takarada. 2007. Cone-building block-and-ash flows: The Senyama volcanic products of O'e Takayama volcano, SW Japan. Bull Volcanol 69: 563-575. 
Kano, K., K. Takeuchi, T. Yamamoto, and H. Hoshizumi. 1991. Subaqueous rhyolite block lavas in the Miocene Ushikiri formation, Shimane peninsula, SW Japan. J Volcanol Geotherm Res 46: 241-253.

Kano, K., K. Uto, and T. Ohguchi. 2007. Stratigraphic review of Eocene to Oligocene successions along the eastern Japan Sea: Implication for early opening of the Japan Sea. J Asian Earth Sci 30: 20-32.

Kano, K., T. Yamamoto, and K. Takeuchi. 1993. A Miocene island-arc volcanic seamount: The Takashibiyama formation, Shimane peninsula, SW Japan. J Volcanol Geotherm Res 59: 101-119.

Kataoka, K.S., T. Matsumoto, T. Saito, et al. 2018. Lahar characteristics as a function of triggering mechanism at a seasonally snow-clad volcano: Contrasting lahars following the 2014 phreatic eruption of Ontake volcano, Japan. Earth Planets Space 70: 113

Kawakatsu, K., and Y. Yamaguchi. 1987. Successive zoning of amphiboles during progressive oxidation in the Daito-Yokota granitic complex, san-in belt, Southwest Japan. Geochim Cosmochim Acta 51: 535-540.

Kay, R.W. 1978. Aleutian magnesian andesites: Melts from subducted Pacific Ocean crust. J Volcanol Geotherm Res 4: 117-132.

Kiji M, Ozawa H, Murata M (2000) Cretaceous adakitic Tamba granitoids in northern Kyoto, San'yo belt, Southwest Japan. (Japanese Title: 京都市北部, 山陽带に分布するアダカイト質丹波花こう岩質岩). Jpn Mag Mineral Petrol Sci 29:136-149

Kimura, J.-I., J.B. Gill, T. Kunikiyo, et al. 2014. Diverse magmatic effects of subducting a hot slab in SW Japan: Results from forward modeling. Geochem Geophys Geosystems 15: 691-739.

Kimura, J.-I., T. Kunikiyo, I. Osaka, et al. 2003. Late Cenozoic volcanic activity in the Chugoku area, Southwest Japan arc during back-arc basin opening and reinitiation of subduction. Island Arc 12: 22-45.

Kimura, J.-I., R.J. Stern, and T. Yoshida. 2005a. Reinitiation of subduction and magmatic responses in SW Japan during Neogene time. Geol Soc Am Bull 117: 969-986.

Kimura, J.-I., M. Tateno, and I. Osaka. 2005b. Geology and geochemistry of Karasugasen lava dome, Daisen-Hiruzen volcano group, Southwest Japan. Island Arc 14: 115-136.

Kiyosugi, K., C.B. Connor, D. Zhao, et al. 2010. Relationships between volcano distribution, crustal structure, and P-wave tomography: An example from the Abu monogenetic volcano group, SW Japan. Bull Volcanol 72: 331-340.

Kiyosugi, K., Y. Horikawa, T. Nagao, et al. 2014. Scoria cone formation through a violent Strombolian eruption: Irao volcano, SW Japan. Bull Volcanol 76: 781

Kling, G.W., M.A. Clark, G.N. Wagner, et al. 1987. The 1986 lake nyos gas disaster in Cameroon, West Africa. Science 236: 169-175.

Komuro, H., M. Aoyama, and T. Arayashiki. 2006. Collapse mechanism of the Paleogene Sakurae cauldron, SW Japan. Bull Volcanol 68: 631

Komuro, H., Ohtsuka, M. (1999) Geologic Structure of the Sakurae Group around Gotsu City and Sakurae Town, Shimane Prefecture. Geosci Rpt Shimane Univ 1885-89 Jpn Engl Abstr 18:85-89.

Koyaguchi, T. 1986. Textural and compositional evidence for magma mixing and its mechanism, Abu volcano group, southwestern Japan. Contrib Mineral Petrol 93: 33-45.

Kumura K, Kanaori Y, Toshida K (2002) K-Ar ages of Aonoyama monogenetic volcanoes and implications for the tectonic evolution of Tokusa and Tsuwano basins. 一般社団法人日本地質学会, p 286.

Kusano, T., and K. Nakayama. 1999. Preliminary report on depositional processes of block-and-ash flow deposits: An example from the Taiheizan pyroclastic flow deposits at Sambe volcano, Southwest Japan. Bull Volcanol Soc Jpn 44: 143-156. https://doi.org/10.18940/kazan.44.3_143.

LeBas, M.J., R.W. Lemaitre, A. Streckeisen, and B. Zanettin. 1986. A chemical classification of volcanic-rocks based on the total alkali silica diagram. J Petrol 27: $745-750$

Maeno, F., S. Nakada, T. Oikawa, et al. 2016. Reconstruction of a phreatic eruption on 27 September 2014 at Ontake volcano, Central Japan, based on proximal pyroclastic density current and fallout deposits. Earth Planets Space 68: 82

Marsh, B. 2004. A magmatic mush column rosetta stone: The McMurdo dry valleys of Antarctica. EOS Trans AGU 85. https://doi.org/10.1029/2004eo470001.

Martin, H., R.H. Smithies, R. Rapp, et al. 2005. An overview of adakite, tonalitetrondhjemite-granodiorite (TTG), and sanukitoid: Relationships and some implications for crustal evolution. Lithos 79: 1-24.

Maruyama, S., Y. Isozaki, G. Kimura, and M. Terabayashi. 1997. Paleogeographic maps of the Japanese Islands: Plate tectonic synthesis from 750 ma to the present. Island Arc 6: 121-142.
Matsuda, T., and M. Oda. 1982. Geology of the late cretaceous to Paleogene igneous rocks in the Kawamoto area, Shimane prefecture, Southwest Japan. J Geol Soc Jpn 88: 31-42.

Matsui, S. 1971. Pyroclastics and their stratigraphy from Volc. Sambe. Earth Sci Chikyu Kagaku 25: 147-163.

Miller, C.F., and D.A. Wark. 2008. Supervolcanoes and their explosive supereruptions. Elements 4: 11-15.

Mimatsu, M. 1962. Showa-Shinzan Diary. Sobetsu, Hokkaido: Memorial Hall.

Minoura, K., and T. Nakata. 1994. Discovery of an ancient tsunami deposit in coastal sequences of Southwest Japan: Verification of a large historic tsunami. Island Arc 3: 66-72.

Miyabuchi, Y., F. Maeno, and S. Nakada. 2015. The October 16, 2013 rainfallinduced landslides and associated lahars at Izu Oshima volcano, Japan. J Volcanol Geotherm Res 302: 242-256.

Miyake, Y. 1994. Geochemistry of igneous rocks of Shimane peninsula, formed within a Miocene back-arc rifting zone at the Japan Sea margin. Geochem $J$ 28: 451-472.

Miyashiro A (1961) Evolution of metamorphic belts. J Petrol 2:277-311.

Miyashiro, A. 1974. Volcanic rock series in island arcs and active continental margins. Am J Sci 274: 321-355. https://doi.org/10.2475/ajs.274.4.321.

Miyashiro, A. 1978. Nature of alkalic volcanic rock series. Contrib Mineral Petrol 66: 91-104.

Morris, P.A. 1995. Slab melting as an explanation of quaternary volcanism and aseismicity in Southwest Japan. Geology 23: 395-398. https://doi.org/10.1130/ 0091-7613(1995)023<0395:SMAAEO>2.3.CO;2.

Morris, P.A., and T. Itaya. 1997. The Matsue formation: Evidence for gross mantle heterogeneity beneath Southwest Japan at 11 ma. Island Arc 6: 337-352.

Morris, P.A., T. Itaya, T. Watanabe, and S. Yamauchi. 1990. Potassium/argon ages of Cenozoic igneous rocks from eastern Shimane prefecture-Oki Dozen island, Southwest Japan and the Japan Sea opening. J SE Asian Earth Sci 4: 125-131.

Morris, P.A., and H. Kagami. 1989. Nd and Sr isotope systematics of Miocene to Holocene volcanic rocks from Southwest Japan: Volcanism since the opening of the Japan Sea. Earth Planet Sci Lett 92: 335-346.

Mukoyoshi, H., S. Kaneki, and T. Hirono. 2018. Slip parameters on major thrusts at a convergent plate boundary: Regional heterogeneity of potential slip distance at the shallow portion of the subducting plate. Earth Planets Space 70: 36

Murakami, H., and H. Komuro. 1993. Sakugi cauldron - Paleogene cauldron in central Chugoku, Southwest Japan. J Geol Soc Jpn 99 243-254 Jpn Engl Abstr 99: 243-254.

Murakami, N., T. Imaoka, and K. Izutsu. 1982. Geology and structure of Paleogene Haza cauldron, Shimane prefecture, Southwest Japan. J Geol Soc Jpn 88: 311-319.

Nakagawa, M., N. Hiraga, and R. Furukawa. 2011. Formation of a zoned magma chamber and its temporal evolution during the historic eruptive activity of Tarumai volcano, Japan: Petrological implications for a long-term forecast of eruptive activity of an active volcano. J Volcanol Geotherm Res 205: 1-16. https://doi.org/10.1016/j.jvolgeores.2011.05.003.

Nakajima, T. 1996. Cretaceous granitoids in SW Japan and their bearing on the crust-forming process in the eastern Eurasian margin. Earth Environ Sci Trans R Soc Edinb 87: 183-191.

Nakajima, T. 2018. Tectonics of sedimentary basins in and around Japan since the opening of the sea of Japan. J Geol Soc Jpn 124: 693-722. https://doi.org/10. 5575/geosoc.2018.0049

Nakajima, T. H. Kamiyama, I.S. Williams, and K. Tani. 2004. Mafic rocks from the Ryoke Belt, Southwest Japan: Implications for cretaceous Ryoke/san-yo granitic magma genesis. Earth Environ Sci Trans R Soc Edinb 95: 249-263.

Nakajima, T., T. Shirahase, and K. Shibata. 1990. Along-arc lateral variation of Rb - $\mathrm{Sr}$ and $\mathrm{K}-\mathrm{Ar}$ ages of cretaceous granitic rocks in Southwest Japan. Contrib Mineral Petrol 104: 381-389. https://doi.org/10.1007/BF01575616.

Németh, K., and G. Kereszturi. 2015. Monogenetic volcanism: Personal views and discussion. Int J Earth Sci 104: 2131-2146.

Nishida, K., T. Imaoka, and S. lizumi. 2005. Cretaceous-Paleogene magmatism in the central san-in district, Southwest Japan: An examination based on $\mathrm{Rb}-\mathrm{Sr}$ isochron ages. J Geol Soc Jpn 111: 123-140.

Northrup, C.J., L.H. Royden, and B.C. Burchfiel. 1995. Motion of the Pacific plate relative to Eurasia and its potential relation to Cenozoic extension along the eastern margin of Eurasia. Geology 23: 719-722.

Otofuji, Y.-I., T. Matsuda, and S. Nohda. 1985. Opening mode of the Japan Sea inferred from the palaeomagnetism of the Japan arc. Nature 317: 603. https://doi.org/10.1038/317603a0. 
Peterson, D.W., and R.I. Tilling. 2000. Lava flow hazards. Encycl Volcanoes: 957-972. Pierson, T.C., J.E. Costa, and W. Vancouver. 1987. A rheologic classification of subaerial sediment-water flows. Debris Flowsavalanches Process Recognit Mitig Rev Eng Geol 7: 1-12.

Pineda-Velasco, I., H. Kitagawa, T.-T. Nguyen, et al. 2018. Production of high-Sr andesite and dacite magmas by melting of subducting oceanic lithosphere at propagating slab tears. J Geophys Res Solid Earth 123: 3698-3728.

Prata, F., and B. Rose. 2015. Volcanic ash hazards to aviation, 911-934. In: The Encyclopedia of Volcanoes. Elsevier.

Rader, E., D. Geist, J. Geissman, et al. 2015. Hot clasts and cold blasts: Thermal heterogeneity in boiling-over pyroclastic density currents. Geol Soc Lond Spec Publ 396: 67-86.

Rosi, M., F. Di Traglia, M. Pistolesi, et al. 2018. Dynamics of shallow hydrothermal eruptions: New insights from Vulcano's breccia di Commenda eruption. Bull Volcanol 80: 83.

Sakai, T., A. Furukawa, and S. Kawano. 2013. Stepwise environmental changes in the lower Miocene koura formation, Southwest Japan, associated with Japan Sea evolution. J Geol Soc Jpn 119: 285-299.

Sassa, K., K. Dang, H. Yanagisawa, and B. He. 2016. A new landslide-induced tsunami simulation model and its application to the 1792 Unzen-Mayuyama landslide-and-tsunami disaster. Landslides 13: 1405-1419.

Sato, D., H. Matsuura, and T. Yamamoto. 2016. Timing of the late cretaceous ignimbrite flare-up at the eastern margin of the Eurasian plate: New zircon $\mathrm{U}-\mathrm{Pb}$ ages from the Aioi-Arima-Koto region of SW Japan. J Volcanol Geotherm Res 310: 89-97.

Sawada, Y., Kadowaki, K., Fujishiro, S., et al (2009) Daisen and Daikonjima volcanoes: Contrasting Quarternary volcanoes in the central part of San-In Province, SW Japan. JourGeolSoc Jpn 115 Suppl P51-70 115:S51-S70.

Sawada Y, Kashine C, Fukue M, et al (2000) Estimation of emplacement temperature of Taiheizan pyrodastic flow deposits from Holocene Sanbe Volcano,Southwest Japan : Were Jomon people affected by pyroclastic flows? (In Japanese with English abstract). Geosci Rept Shimane Univ 19 P 3-15.

Schmincke H-U (1977) Phreatomagmatische Phasen in quartären Vulkanen der Osteifel. Schmincke H-U (2004) Volcanism. Springer Science \& Business Media.

Shin, K.-C., M. Kurosawa, R. Anma, and T. Nakano. 2009. Genesis and mixing/ mingling of mafic and felsic magmas of Back-arc granite: Miocene Tsushima pluton, Southwest Japan. Resour Geol 59: 25-50

Song, K., F. Wang, Z. Dai, et al. 2019. Geological characteristics of landslides triggered by the 2016 Kumamoto earthquake in Mt. Aso volcano, Japan. Bull Eng Geol Environ 78: 167-176.

Sparks, R.S.J., and L. Wilson. 1976. A model for the formation of ignimbrite by gravitational column collapse. J Geol Soc 132: 441-451.

Sparks, S.R., H. Sigurdsson, and L. Wilson. 1977. Magma mixing: A mechanism for triggering acid explosive eruptions. Nature 267: 315.

Sulpizio, R., P. Dellino, D.M. Doronzo, and D. Sarocchi. 2014. Pyroclastic density currents: State of the art and perspectives. J Volcanol Geotherm Res 283: 36-65.

Suzuki, K., and M. Adachi. 1994. Middle Precambrian detrital monazite and zircon from the Hida gneiss on Oki-Dogo Island, Japan: Their origin and implications for the correlation of basement gneiss of Southwest Japan and Korea. Tectonophysics 235: 277-292.

Taira, A. 2001. Tectonic evolution of the Japanese island arc system. Annu Rev Earth Planet Sci 29: 109-134.

Takasu A (1989) PT histories of peridotite and amphibolite tectonic blocks in the Sanbagawa metamorphic belt, Japan. Geol Soc Lond Spec Publ 43:533-538.

Tatsumi, Y., R. Arai, and K. Ishizaka. 1999. The petrology of a melilite-olivine nephelinite from Hamada, SW Japan. J Petrol 40: 497-509.

Tedesco, D., O. Vaselli, P. Papale, et al. 2007. January 2002 volcano-tectonic eruption of Nyiragongo volcano. Democratic Republic of Congo J Geophys Res Solid Earth 112

Thordarson, T., and S. Self. 1993. The Laki (Skaftár Fires) and Grímsvötn eruptions in 1783-1785. Bull Volcanol 55: 233-263.

Todesco, M. 2017. The leap in the dark: Geological thoughts about an unpredictable planet. J Geophys Res Solid Earth 122: 2780-2783.

Tomiya, A., I. Miyagi, G. Saito, and N. Geshi. 2013. Short time scales of magmamixing processes prior to the 2011 eruption of Shinmoedake volcano, Kirishima volcanic group, Japan. Bull Volcanol 75: 750

Tsukui, M. 1985. Temporal variation in chemical composition of phenocrysts and magmatic temperature at Daisen volcano, Southwest Japan. J Volcanol Geotherm Res 26: 317-336.
Ui, T., N. Matsuwo, M. Sumita, and A. Fujinawa. 1999. Generation of block and ash flows during the 1990-1995 eruption of Unzen volcano, Japan. J Volcanol Geotherm Res 89: 123-137.

USGS (2018) USGS: Volcano Hazards Program HVO Kilauea. https://volcanoes.usgs. gov/volcanoes/kilauea/multimedia_maps.html.

Uto, K., E. Takahashi, E. Nakamura, and I. Kaneoka. 1994. Geochronology of alkali volcanism in Oki-Dogo Island, Southwest Japan: Geochemical evolution of basalts related to the opening of the Japan Sea. Geochem J 28: 431-449.

Valentine, G.A., and C.B. Connor. 2015. Basaltic volcanic fields, 423-439. In: The Encyclopedia of Volcanoes. Elsevier.

Voight, B. 1990. The 1985 Nevado del Ruiz volcano catastrophe: anatomy and retrospection. J Volcanol Geotherm Res 42: 151-188.

Wada, H., S. Harayama, and Y. Yamaguchi. 2004. Mafic enclaves densely concentrated in the upper part of a vertically zoned felsic magma chamber: The Kurobegawa granitic pluton, Hida Mountain range, Central Japan. Geol Soc Am Bull 116: 788-801.

Wakita, K. 2013. Geology and tectonics of Japanese islands: A review-the key to understanding the geology of Asia. J Asian Earth Sci 72: 75-87.

Watanabe, S., E. Widom, T. Ui, et al. 2006. The evolution of a chemically zoned magma chamber: The 1707 eruption of Fuji volcano, Japan. J Volcanol Geotherm Res 152: 1-19.

Watt, S.F.L., M. Jutzeler, P.J. Talling, et al. 2015. New insights into landslide processes around volcanic islands from remotely operated vehicle (ROV) observations offshore Montserrat. Geochem Geophys Geosystems 16: 2240-2261.

White, J.D. 1996. Impure coolants and interaction dynamics of phreatomagmatic eruptions. J Volcanol Geotherm Res 74: 155-170.

Wilson BM (2007) Igneous petrogenesis a global tectonic approach. Springer Science \& Business Media

Wilson, C.J.N., B.F. Houghton, M.O. McWilliams, et al. 1995. Volcanic and structural evolution of Taupo volcanic zone, New Zealand: A review. J Volcanol Geotherm Res 68: 1-28.

Yakushiij, A., A. Kamei, and T. Shibata. 2012. Igneous activity forming hybrid rocks and leucogranites in the Obara area, San'in zone, Southwest Japan. J Geol Soc Jpn 118: 20-38.

Yamaguchi, Y., H. Wada, Y. Ohta, and S. Harayama. 2003. Amphibole zoning, a record of progressive oxidation during crystallization of mafic microgranular enclaves in the Kurobegawa granitic pluton. J Mineral Petrol Sci 98: 151-155.

Yamamoto, T. 2017. Quantitative eruption history of Pleistocene Daisen volcano, SW Japan. Bull Geol Surv Jpn 68: 1-16.

Yamamoto, Y., Y. Ogawa, T. Uchino, et al. 2007. Large-scale chaotically mixed sedimentary body within the late Pliocene to Pleistocene Chikura group, Central Japan. Island Arc 16: 505-507.

Zeng, N., E. Izawa, K. Watanabe, and Y. Motomura. 2010. Hydrothermal alteration related to silver mineralization at the Iwami silver deposit, Shimane prefecture, Japan. Resour Geol 60: 234-248. https://doi.org/10.1111/j.1751 3928.2010.00129.x.

Zhao, D., T. Yanada, A. Hasegawa, et al. 2012. Imaging the subducting slabs and mantle upwelling under the Japan Islands. Geophys J Int 190: 816-828.

\section{Publisher's Note}

Springer Nature remains neutral with regard to jurisdictional claims in published maps and institutional affiliations.

\section{Submit your manuscript to a SpringerOpen ${ }^{\circ}$ journal and benefit from:}

- Convenient online submission

- Rigorous peer review

- Open access: articles freely available online

- High visibility within the field

- Retaining the copyright to your article

Submit your next manuscript at $\boldsymbol{\nabla}$ springeropen.com 